\title{
Response of Carbon and Nitrogen Pools of Vegetation, Soil and Microbe to Different Land-use Patterns in Arid and Semi-arid Grasslands
}

\author{
Xiuli Gao ${ }^{1}$, xiao guan ${ }^{1}$, yao $\operatorname{liu}^{2}$, kui li ${ }^{1}$, wang wang $^{1}$, and hai lv ${ }^{1}$ \\ ${ }^{1}$ Chinese Research Academy of Environmental Sciences \\ ${ }^{2}$ Chinese Academy of Sciences
}

February 23, 2022

\begin{abstract}
Previous studies have demonstrated positive net primary production effects with in-creased precipitation in semi-arid grasslands of Inner Mongolian. The knowledge of the store and storage potential of carbon (C) and nitrogen (N) can help us to under-stand how ecosystems would respond to anthropogenic disturbances under different management strategies. Therefore, we carried out research on the storage of organic $\mathrm{C}$ and $\mathrm{N}$ in four sites where the floras and landform were similar but the intensities of disturbance by grazing animals varied. The primary objective of this study was to pinpoint how the store and storage potential of $\mathrm{C}$ and $\mathrm{N}$ would respond to grazing exclusion and precipitation. We determined concentrations of both soil organic car-bon (SOC) and soil total nitrogen (TN) in the $0-50 \mathrm{~cm}$ soil layers. Concentrations of microbial biomass carbon (MBC) and microbial biomass nitrogen $(\mathrm{MBN})$ were measured by an innovative method in our study. Additionally, soil bacteria and fungi content were determined in the 0-50 cm soil layers. The total C, N, MBC and MBN storage were significantly different among the four grasslands $(\mathrm{P}<0.05)$, and they all decreased substantially with grassland degradation and increased to a significant extent with the introduction of natural grassland (ND). More than $90 \% \mathrm{C}$ and $95 \% \mathrm{~N}$ stored in soil were lost, while they were minor in other pools (including those stored in above-ground biomass, litter, and roots). It is inter-esting to note that micro-aggregate is a limiting factor to soil and microbial nutrients pool compared to precipitation. The limit range of $\mathrm{C}$ and $\mathrm{N}$ storage observed in these grassland soils suggests that enclosed-fence may be a valuable mechanism of seques-tering $\mathrm{C}$ in the top meter of the soil profile. The results of this study can provide a basis for better recovery of grassland that grazing disturbed in semi-arid areas.
\end{abstract}

Response of Carbon and Nitrogen Pools of Vegetation, Soil and Microbe to Different Land-use Patterns in Arid and Semi-arid Grasslands

Xiuli Gao ${ }^{1,2}$, Xiao Guan ${ }^{1,2}$, Junyao $\mathrm{Liu}^{1,3}$, Daikui $\mathrm{Li}^{1,2}$, Dewang Wang ${ }^{1,2}$, Shihai $\mathrm{Lv}^{1,2,{ }^{*}}$

${ }^{1}$ State Key Laboratory of Environmental Criteria and Risk Assessment, Chinese Research Academy of Environmental Sciences, Beijing 100012, China

${ }^{2}$ Chinese Research Academy of Environmental Sciences,Beijing 100012, China

${ }^{3}$ State Key Laboratory of Vegetation and Environmental Change, Institute of Botany, Chinese Academy of Sciences, Haidian District, Beijing 100093 China

${ }^{4}$ National Environmental Protection Hulunber Forest-Steppe Ecotone Observation and Research Station,Hulunber 021000, China

* Corresponding author. 
*E-mail: lv_sh@craes.org.cn

\begin{abstract}
Previous studies have demonstrated positive net primary production effects with increased precipitation in semi-arid grasslands of Inner Mongolian. The knowledge of the store and storage potential of carbon (C) and nitrogen $(\mathrm{N})$ can help us better understand how ecosystems would respond to anthropogenic disturbances under different management strategies. Therefore, we carried out research on the storage of organic $\mathrm{C}$ and $\mathrm{N}$ in four sites where the floras and landform were similar but the intensities of disturbance by grazing animals varied. The primary objective of this study was to pinpoint how the store and storage potential of $\mathrm{C}$ and $\mathrm{N}$ would respond to grazing exclusion and precipitation. So, the concentrations of soil organic carbon (SOC) and soil total nitrogen (STN) were determined in the $0-50 \mathrm{~cm}$ soil layers, and the concentrations of microbial biomass carbon (MBC) and microbial biomass nitrogen (MBN) were measured by an innovative method in our study. Additionally, the contents of soil bacteria and fungi were determined in the 0-50-cm soil layers.

The research showed that the total C, N, MBC and MBN storage were significantly different among the four grasslands $(P<0.05)$, and they all decreased substantially with grassland degradation and increased to a significant extent with the introduction of natural grassland (NG). More than $90 \%$ of $\mathrm{C}$ and $95 \%$ of $\mathrm{N}$ stored in soil were lost, while they were minor in other pools (including those stored in the above-ground biomass, litter, and roots). It is interesting to note that micro-aggregate was a limiting factor to soil and microbial nutrients pool compared to precipitation. The limit range of $\mathrm{C}$ and $\mathrm{N}$ storage observed in these grassland soils suggested that enclosed-fence might be a valuable mechanism of sequestering $\mathrm{C}$ in the top meter of the soil profile. The results of this study can provide a basis for better recovery of the grasslands that grazing disturbed in semi-arid areas.
\end{abstract}

Keywords : soil organic carbon; microbial activity; semi-arid steppe

\title{
1. Introduction
}

About $40 \%$ of the land surface in the world are covered by grasslands (White et al., 2000), most of which are in drylands (Maestre et al.,2012) and sustain the main livestock-production systems (Kemp et al., 2013); Soil contains more carbon than the atmosphere and vegetation combined (Averill C et al., 2014). In some areas, grasslands may serve as important global $\mathrm{C}$ sinks. For those in the tropics, the annual sink is about $0.5 \mathrm{Pg}$ of $\mathrm{C}$ and it is basically influenced by the baseline of SOC level and annual precipitation (Davidson et al., 1995; Scurlock and Hall, 1998; Tan et al., 2006). Moreover, they store 200-300 Pg of soil carbon, which influences the global carbon cycle significantly (Scurlock and Hall, 1998).

The significant impacts of the differences in land-use and ecosystem management strategies on the storage of $\mathrm{C}$ in grasslands has been shown clearly in the past few decades (Lugo and Brown, 1993; Post and Kwon, 2000; Jones and Donnelly, 2004; Billings, 2006; Elmore and Asner, 2006; Liao et al., 2006). Meanwhile, nitrogen is vital for vegetation productivity as well as terrestrial ecosystem stability (Harpole et al., 2007). Due to the close connection of soil $\mathrm{C}$ and $\mathrm{N}$ cycles, there is substantive concern that the changes in land-use and its integrative effect may alter the storage of $\mathrm{C}$ and $\mathrm{N}$ in the soil (Houghton et al., 1999). For instance, in the northern China, the severe degradation or desertification of temperate grasslands was just led by rapid livestock expansion (Li, 1994; Dong and Zhang, 2005). The improvement of soil nutrient availability can help the plant recover from a disturbance, promote the fast-growing plants to regrow faster given a improved soil water status, and then facilitate the recovery of plant growth in an ecosystem (Stampfli et al., 2018). Obviously, nitrogen and water availability is of important impacts on the net primary productivity (NPP) of grasslands (Xu et al., 2014), especially those in semi-arid regions where annual precipitation inputs are significantly less than evaporation (Heisler-White et al., 2008). After the drought, $\mathrm{N}$ availability could be triggered; meanwhile, there would be improvements in plant absorption, reallocation and N-use efficiency (Mackie et al., 2019). The soil $\mathrm{N}$ availability could affect the composition of microbial community and the richness of soil bacteria and fungi.

However, there is a dearth of information regarding the potential of $\mathrm{C}$ and $\mathrm{N}$ storage due to the absence 
of stable or mature grassland ecosystems. The knowledge of the store and storage potential of carbon (C) and nitrogen $(\mathrm{N})$ can help us understand how ecosystems would respond to anthropogenic disturbances under different management strategies. Therefore, we conducted a study on organic $\mathrm{C}$ and $\mathrm{N}$ storage in four sites that were floristically and topographically similar to ascertain the impact of grazing exclusion and precipitation on the store and storage potential of $\mathrm{C}$ and $\mathrm{N}$. This study can provide a basis for recovery of the grasslands that grazing disturbed in semi-arid areas.

\section{Materials and Methods}

\subsection{Study Site and Experiment Design}

The study site $\left(42^{\circ} 02^{\prime} 27^{\prime \prime} \mathrm{N}, 116 \mathrm{deg} 17^{\prime} 59^{\prime \prime}\right.$ E, elevation 1,334 m a.s.l) is located in the south of Duolun County of Inner Mongolia, northern China. The site has a semi-arid climate with mean annual precipitation of 379.4 $\mathrm{mm}$ and mean annual temperature of $2.1 \mathrm{degC}$, ranging from $-17.8 \mathrm{deg} \mathrm{C}$ in January to $18.8 \mathrm{deg} \mathrm{C}$ in July. The mean annual precipitation from January to June is $118.8 \mathrm{~mm}$ and January to August $306.7 \mathrm{~mm}$. The mean annual temperature from January to June is $0.1 \mathrm{degC}$ and January to August $4.69 \mathrm{degC}$. The soil pH of the experimental site is ranging from $7.1(P=0.04)$ to $7.4(P=0.003)$ under precipitation. It is featured by a chestnut soil (Chinese Soil Taxonomy) or Calcisorthic Aridisol (the U.S. Soil Taxonomy). The steppe in that region has been severely degraded due to overgrazing in the past 50 years. In this study, four experimental sites were selected and subjected to SD, MD, LD, and NG respectively (Table 1). Site SD had been exposed to long-term heavy grazing; and an estimated $90 \%$ of the above-ground biomass had been consumed by livestock every year. As indicated, the grasslands were severely degraded by the extremely sparse vegetation coverage $(<10 \%)$. Site MD had also been exposed to long-term heavy grazing, with an estimated $75 \%$ of the above-ground biomass consumed by livestock every year. It was moderately degraded with an existing vegetation cover of $10-25 \%$. Site LD had been subjected to long-term free-grazing, and an estimated $65 \%$ of the above-ground biomass had been consumed by livestock every year with existing vegetation cover of 25-30\%. Influenced by climatic conditions and human activities, the dominant vegetation on aeolian soil was Spiraea saliclfolia and Salix gordejevii. Associated species were Leymus chinensis, Agropyron cristatum, etc. Site NG was set up in 2000 by fencing a 40 ha of a previously free-grazing grassland when the local government initiated a grassland protection program (Xu et al. 2012). Natural grassland (NG) is dominated by needlegrass (Stipa krylovii), wheatgrass (Agropyron cristatum), and prairie sagewort (Artemisia frigida). It is undeniable that there are pseudo-replication issues given that there is only one plot per grazing regime, and in these studies, this problem is quite common. However, it should be certain that changes in SOC and STN among the four plots in this study are mainly caused by grazing intensity and length of exclusion because the four experimental plots are floristically and topographically similar and all are distributed in the same upper basalt platform (Table 1)

\subsection{Field Sampling and Laboratory Analysis}

In early April 2017, we selected representative plots at site SD, MD, LD, and NG to measure the aboveground and below-ground $\mathrm{C}$ and $\mathrm{N}$ contents in plants, litter and roots. The field samplings conducted in mid-June and mid-August 2017 in Inner Mongolia were taken as the research objects. In each plot, 5 sampling quadrats (each $1 \mathrm{~m} * 1 \mathrm{~m}$ ) were set up at 10-m intervals along a random transect. (The information on vegetation and soil types can be acquired fromhttp://www.maplet.org .) The above-ground samples in plants and litter were collected subsequently. Root samples were determined by a soil corer (diameter $7 \mathrm{~cm})$, with 5 sampling points for each site. Similarly, soil sampling was conducted by a soil sampler (diameter, $4 \mathrm{~cm}$ ), and the soil samples were separately collected from five layers at the depths of $0-10 \mathrm{~cm}, 10-20 \mathrm{~cm}$, $20-30 \mathrm{~cm}, 30-40 \mathrm{~cm}$, and $40-50 \mathrm{~cm}$ in each sampling point.

\subsection{Chemical Analysis}

(1) The $\mathrm{pH}$ of $0-10 \mathrm{~cm}$ soil samples, in $\mathrm{H}_{2} \mathrm{O}$ (soil : water 1:5), was tested with a PHS-3S pH meter (Sartorius, Germany).

(2) Soil aggregates were fractionated by a laser particle size analyzer. For particle-size fraction (i.e. into 
sand, silt, and clay), $50 \mathrm{~g}$ of soil $(<2 \mathrm{~mm})$ was dispersed in $250 \mathrm{ml}$ of distilled water with a KS-600 probe-type Ultrasonic Cell Disrupter System (Shanghai Precision \& Scientific Instrument Co. Ltd., China) set at 360 W; then the different particle-size fractions were detached as per Morra et al.(1991). After isolation, large macro-aggregates $(>2000 \mu \mathrm{m})$, small macro-aggregates $(250-2000 \mu \mathrm{m})$, and micro-aggregates $(<250 \mu \mathrm{m})$ were extracted.

(3) The contents (\%) of organic C in the samples of plant, litter, root, and soil were measured by a modified Mebius method separately (Nelson and Sommers, 1982). Then, $0.5 \mathrm{~g}$ samples were digested with $5 \mathrm{~mL}$ SOC solution. The concentration of SOC was determined by chemical oxidation with $\mathrm{K}_{2} \mathrm{Cr}_{2} \mathrm{O}_{7}$ solution. Then, approximately $0.2 \mathrm{~g}$ air-dried soil was weighed in separate test tubes, with analytical replication for each sample and a total of 5 sub-samples from each treatment. Exactly $10 \mathrm{~mL}$ of reaction solution containing $0.032 \mathrm{Mol} \mathrm{Ag}_{2} \mathrm{SO}_{4}, 0.06667 \mathrm{Mol} \mathrm{K}_{2} \mathrm{Cr}_{2} \mathrm{O}_{7}$, and $9.39 \mathrm{Mol} \mathrm{H}_{2} \mathrm{SO}_{4}$ was added to each tube which was then

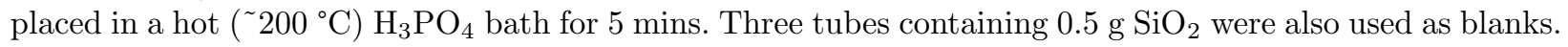
The amount of $\mathrm{K}_{2} \mathrm{Cr}_{2} \mathrm{O}_{7}$ consumed by SOC oxidation was determined by titrating the remaining $\mathrm{K}_{2} \mathrm{Cr}_{2} \mathrm{O}_{7}$ in the test tubes after digestion. The SOC oxidation efficiency was determined to be $92 \%$, thus a 1.08 correction factor was used. The total N (\%) of plant, litter, root, and soil was measured with the modified Kjeldahl wet digestion procedure (Gallaher et al., 1976) with a 2300 Kjeltec Analyzer Unit (FOSS, Sweden). Then, 0.5 $\mathrm{g}$ of air-dried and finely ground soil, in duplicate, were taken for each sample. Afterwards, the soil samples were digested with $18.76 \mathrm{Mol} \mathrm{H}_{2} \mathrm{SO}_{4}$ for $6 \mathrm{hrs}$ under progressively elevated temperature from $150 \operatorname{degC}$ (1 hr), $270 \operatorname{deg} \mathrm{C}(1 \mathrm{hr})$ to $380 \mathrm{degC}(4 \mathrm{hrs})$ and then automatically distilled in a Kjeldahl apparatus where the evolved $\mathrm{NH}_{3}$ was adsorbed by $\mathrm{H}_{3} \mathrm{BO}_{3}\left(20 \mathrm{~g} \mathrm{~L}^{-1}\right)$. The yield of $\mathrm{NH}_{3}$ was titrated by diluted $\mathrm{H}_{2} \mathrm{SO}_{4}(0.02$ $\mathrm{Mol}$ ) and converted into the total amount of nitrogen in soil.

(4) Soil microbial biomass analysis. Soil microbial biomass C (MBC) and N (MBN) were determined by the fumigation-extraction method (Vance et al. 1987). In this study, an innovative method, a soil microbial fumigation device and an improved fumigation method (ZL 20203 0785811.3) were employed to extract microbial biomass. During the process of microbial fumigation, the traditional glass drying dish needs to be sealed with paraffin wax, which is not only poor in sealing, but also difficult to control the temperature of constant temperature culture. Therefore, vacuum pump is required in the process of culture to maintain a certain negative pressure. However, it would be challenging to maintain the same batch of samples under the same negative pressure, thus resulting in greater individual differences in the fumigation of samples. Additionally, the result of removing chloroform from the container is not ideal after fumigation. It could be claimed that the employment of the patented device could definitely resolve the defects of the prior art. Then, $10 \mathrm{~g}$ of each soil sample was fumigated with ethanol-free chloroform $\left(\mathrm{CHCl}_{3}\right)$ for $24 \mathrm{hrs}$ at 25 - Meanwhile, another sub-sample was kept at the same conditions without fumigation. After $\mathrm{CHCl}_{3}$ was fully removed, organic $\mathrm{C}$ from fumigated and unfumigated soil samples were extracted with $0.5 \mathrm{Mol}_{2} \mathrm{SO}_{4}$, with a soil: extractant ratio of 1:4 (w/v), and shaken at $150 \mathrm{rpm}$ for $1 \mathrm{hr}$. Then, extractable organic $\mathrm{C}$ in soil extracts was analyzed by a TOC analyzer (High TOC, Elementar) after the filtration with Whatman no. $2 \mathrm{v}$ filter paper. The microbial biomass $\mathrm{C}$ and $\mathrm{N}$ were measured as the difference between fumigated and non-fumigated samples and normalized to the weight of the soil fraction.

(5) The PLFAs were extracted, fractionated, and quantified as described by Bossio and Scow (1998). Frozen soil aggregate samples (equivalent to $8 \mathrm{~g}$ dry mass of soil) were extracted by a mixture of methanol, chloroform $\left(\mathrm{CHCl}_{3}\right)$, and phosphate buffer in a volumetric ratio of $(2: 1: 0.8)$ for $2 \mathrm{hrs}$. The sediment was extracted for another 30 mins. After the extractions, the supernatants were transferred to a separation funnel and put to rest overnight. After the separation, the $\mathrm{CHCl}_{3}$ layer was obtained and dried under $\mathrm{N}_{2}$. Through the elution with $\mathrm{CHCl}_{3}$, acetone, and methanol successively by silica-bonded phase columns, the polar lipids were separated from neutral lipids and glucolipids (Supelco Inc., Bellefonte, PA). By a mild alkali methanolysis, polar lipids were converted into fatty acid methyl esters. The extractants were then redissolved in $300 \mu \mathrm{L}$ hexane which contained methyl nonadecanoate fatty acid as an internal standard. Samples were analyzed by an Agilent 6850 gas chromatograph coupled with a flame ionization detector and a HP-5 capillary column $(25.0 \mathrm{~m} \times 200 \mu \mathrm{m} \times 0.33 \mu \mathrm{m})$. Peaks were identified with a microbial identification system (Microbial ID. Inc., Newark, DE, USA). In this study, fatty acids with percentages higher than $0.5 \%$ of the total 
were considered. The i14:0, i15:0, a15:0, i16:0, i17:0, 14:1O5c, 16:107c, cy17:0, 17:106c, 17:1O8c, 18:107c, cy19:0, 16:1 2OH and a17:0 were used as biomarkers for Germ, while the 18:1O9c, 18:2O6c, 18:3O6, 16:1O5, 10me16:0, 10me17:0 and 10me18:0PLFAs were used as biomarkers for fungi (Zak et al. 1996; Pinkart et al. 2002; Zhang et al. 2015; DeForest et al).

\subsection{Statistical Analysis}

All data were expressed as mean \pm 1 standard error of mean(SEM). The data for the $0-50$-cm soil layer were used to analyze the $\mathrm{C}$ and $\mathrm{N}$ storage potentials of the grassland. An analysis of variance (ANOVA) was used to assess the effect of land-use change on $\mathrm{C}$ and $\mathrm{N}$ storage and microbiological differences. All statistical analysis were performed with the software program $\mathrm{R}(3.4 .1)$. The meteorological data of this study are sourced from China Meteorological Data Network (http://www.worldclim.org). Sigmplot and R software were used for mapping.

\section{Results}

\subsection{Variate of Carbon and Nitrogen Pools}

\subsubsection{Soil Carbon and Nitrogen Pools}

The values of the total soil $\mathrm{C}$ storage differed significantly among the four sites $(P<0.01)$, varying from $0.4 \mathrm{~g} \mathrm{C} \mathrm{kg}^{-1}$ for plot SD to $17.5 \mathrm{~g} \mathrm{C} \mathrm{kg}^{-1}$ for plot NG. Similarly, the values of the total N storage differed markedly among the four sites $(P<0.01)$, varying from $0.03 \mathrm{~g} \mathrm{~N} \mathrm{~kg}^{-1}$ for plot MD to $1.7 \mathrm{~g} \mathrm{~N} \mathrm{~kg}^{-1}$ for plot NG (Fig. 1). The total $\mathrm{C}$ storage decreased substantially with grassland degradation, and increased to a significant extent with the introduction of NG. The C concentration in soil was far higher in the 0-10-cm, 10-20-cm and 20-30-cm soil layers than in other soil layers (Fig. 1a). The N concentration in soil was far higher in the $0-10-\mathrm{cm}$ and 10-20-cm soil layers than in other soil layers (Fig. 1b).

Compared to SD, NG increased the total C and N storage in the 0-50-cm soil layer by $97.3 \%$ and $98.1 \%$, with an annual increase rate of $1.71 \%$ and $1.72 \%$, respectively. The total $\mathrm{C}$ and $\mathrm{N}$ storage increased logarithmically with the duration of NG $(P<0.05)$ (Fig.1).

\subsubsection{Vegetation Carbon and Nitrogen Pools}

The $\mathrm{C}$ and $\mathrm{N}$ stored in the above-ground biomass were less than $537.2 \mathrm{~g} \mathrm{C} \mathrm{kg}^{-1}$ and $20.1 \mathrm{~g} \mathrm{~N} \mathrm{~kg}^{-1}$, respectively (Fig. 2), the $\mathrm{C}$ and $\mathrm{N}$ stored in the roots were less than $503.5 \mathrm{~g} \mathrm{C} \mathrm{kg}^{-1}$ and $16.5 \mathrm{~g} \mathrm{~N} \mathrm{~kg}^{-1}$, respectively., and the $\mathrm{C}$ and $\mathrm{N}$ stored in the litter were less than $510.0 \mathrm{~g} \mathrm{C} \mathrm{kg}^{-1}$ and $16.6 \mathrm{~g} \mathrm{~N} \mathrm{~kg}^{-1}$, respectively, accounting for negligible amounts $(<1 \%$ of the total) of total $\mathrm{C}$ and $\mathrm{N}$ storage in the ecosystem. The total $\mathrm{C}$ storage (including $\mathrm{C}$ stored in above-ground biomass, litter, roots, and $0-50-\mathrm{cm}$ soil layers) differed significantly among the four sites $(P<0.01)$, and the $\mathrm{C}$ storage varied remarkably among the different pools (Fig. 1 and Fig.2). The amount of $\mathrm{C}$ stored in plants accounted for over $90 \%$ of the total $\mathrm{C}$ storage, the $\mathrm{C}$ stored in soil was very low $(<10 \%)$, compared to other pools, and the amount of $\mathrm{C}$ stored in the roots varied from $8.5 \mathrm{~g} \mathrm{C} \mathrm{kg}^{-1}$ for plot SD to $432.1 \mathrm{~g} \mathrm{C} \mathrm{kg}^{-1}$ for plot NG. Similarly, the total N storage (including N stored in above-ground biomass, litter, and roots) differed significantly among different grasslands $(P<0.01)$. The total $\mathrm{N}$ storage varied from $8.5 \mathrm{~g} \mathrm{~N} \mathrm{~kg}^{-1}$ for plot $\mathrm{SD}$ to $12.5 \mathrm{~g} \mathrm{~N} \mathrm{~kg}^{-1}$ for plot NG (Fig. 2).

The $\mathrm{C}$ and $\mathrm{N}$ storage varied remarkably among the different pools at different season, increase or decrease among the different pools (Fig. 2a and Fig.2b).

The $\mathrm{N}$ stored in litter and roots was very low, compared to that in above-ground biomass (Fig. 2).

\subsubsection{Microbial Biomass Carbon and Nitrogen Pools}

The values of MBC storage differed significantly among the four sites $(P<0.01)$, varying from $0.9 \mathrm{mg} \mathrm{MBC}$ $\mathrm{kg}^{-1}$ for plot MD to $200.7 \mathrm{mg} \mathrm{MBC} \mathrm{kg}{ }^{-1}$ for plot NG (Fig. 3a). Similarly, the values of MBN storage differed significantly among the four sites $(P<0.01)$, varying from $0.8 \mathrm{mg} \mathrm{N} \mathrm{kg}{ }^{-1}$ for plot MD to $32.0 \mathrm{mg} \mathrm{N} \mathrm{kg} \mathrm{g}^{-1}$ for plot NG (Fig. 3b). The $\mathrm{C}$ stored in the MD were less than $26.9 \mathrm{mg} \mathrm{MBC} \mathrm{kg}{ }^{-1}$ and $4.41 \mathrm{~g} \mathrm{MBN} \mathrm{kg}^{-1}$,

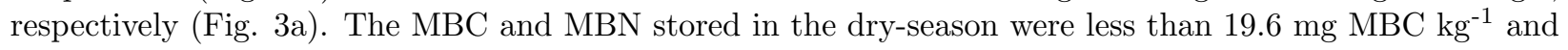


$6.25 \mathrm{mg} \mathrm{MBN} \mathrm{kg}{ }^{-1}$ among the MD, respectively, while the MBC and MBN stored in the wet-season were less than $26.7 \mathrm{mg} \mathrm{MBC} \mathrm{kg}-1$ and $2.2 \mathrm{mg} \mathrm{MBN} \mathrm{kg}^{-1}$ among the MD, respectively. The total MBC storage (including MBC stored in the $0-50$-cm soil layers) differed significantly among the four sites $(P<0.01)$. The total MBC storage decreased substantially with grassland degradation, and increased to a significant extent with the introduction of NG (Fig. 3).

The amount of MBC stored in NG accounted for over $70 \%$ of the total MBC storage in the site, and the MBC stored in deep-soil layer was very low $(<20 \%)$, compared to other layers. The amount of MBN stored in the soil varied from $0.5 \mathrm{~g} \mathrm{MBN} \mathrm{mg} \mathrm{kg}^{-1}$ for plot MD to36.5 mg MBN kg${ }^{-1}$ for plot NG.

The MBN concentration in soil was far higher in the 0-10-cm, 10-20-cm, and 20-30-cm soil layer than in other soil layers (Fig. 3).

The total MBC and MBN storage varied remarkably among the different seasons $(P<0.01)$, increase or decrease among the different pools (Fig. 3a and Fig.3b).

Compared to NG, more than $90 \%$ of the soil microbial biomass in MD had been lost. Compared to MD, NG increased the total MBC and MBN storage in the $0-50-\mathrm{cm}$ soil layer by $93.5 \%$ and $90.7 \%$, respectively.

The total MBC and MBN storage did show a similar trend of increase with the duration of NG $(\mathrm{P}<0.05)$ (Fig. 3).

\subsubsection{Bacteria and Fungi Pools}

The content of sand and gravel contributed more to soil fungi and had a positive effect (Fig. 8). Microorganisms were not always limited by soil $\mathrm{C}$ and $\mathrm{N}$, and the bacteria and fungi storage did not show a similar trend of increase with the duration of NG $(P<0.05)$. The percentage of bacteria and fungi varied remarkably among the different grazing pools (Fig. 4). The variation range of soil bacteria percentage in dry-season was $26.5 \% \sim 40.7 \%$ and wet-season $5.4 \% \sim 47.0 \%$, respectively, while the variation range of soil fungi percentage in dry-season was $3.9 \% \sim 10.42 \%$ and wet-season $1.3 \% \sim 8.9 \%$, respectively.

In different desertification, the overall trend of soil fungi is that SD has the lowest level, and MD and LD are similar (Fig. 4).

Our results partially supported a decreased contribution of fungi PLFAs in wet-season compared to dryseason (in the 0-40-cm soil layers) and an increased contribution of fungi PLFAs in wet-season compared to dry-season (in the 40-50-cm soil layers) (Fig.4a and Fig.4b). With the increase of precipitation, soil bacteria and fungi significantly increased or decreased, which indicated that soil microorganism was greatly influenced by precipitation patterns. Bacteria and fungi content are found both highest in dry-season among MD and LD, while the highest content of bacteria and fungi may be distributed in wet-season among NG. Additionally, they are remarkably different from lowest to highest content, $\mathrm{SD}<\mathrm{MD}<\mathrm{LD}<\mathrm{NG}$, in wetseason. The distribution of soil bacteria in the surface layer was significantly higher than that in the bottom layer (0-30cm) among SD, MD, and LD (Dry-season, Fig.4a).

3.2 Relationship between Nutrient Pools and Grazing Intensity

\subsubsection{Effects of Soil Aggregate Size on Grazing Intensity}

Compared to SD, NG can increase silt and clay storage in the $0-50-\mathrm{cm}$ soil layer by $90.2 \%$ and $90.5 \%$ (annual increase rates), respectively. In wet-season, changes in grazing management can lead to annual increases of about $1.3 \%$ and $1.4 \%$ in silt $\left(\mathrm{R}^{2}=0.97\right)$ and clay $\left(\mathrm{R}^{2}=0.88\right)$ storage, respectively. The soil silt storage sustained an initial rapid increase with the introduction of $\mathrm{NG}$, followed by a steady phase of silt storage with grazing time (Fig. 6).

\subsubsection{Relationship between Soil Nutrient Pools and Grazing Gradient}

Compared to SD, NG can increase C and N storage in the $0-50-\mathrm{cm}$ soil layer by $97.3 \%$ and $98.1 \%$, and the annual increase rates are both about $1.7 \%\left(\mathrm{R}^{2}>0.89 ; \mathrm{R}^{2}[?] 0.98\right)$ for $\mathrm{C}$ and $\mathrm{N}$, respectively. Moreover, the 
total soil $\mathrm{C}$ content is, to a certain extent, dependent on the type of land-use. The soil $\mathrm{C}$ and $\mathrm{N}$ storage sustained an initial rapid increase with the introduction of NG (Fig. 6).

\subsubsection{Relationship between Plant Nutrient Pools and Grazing}

In our study, regression analysis indicated that there were less relationship between plant nutrients (including $\mathrm{C}$ and $\mathrm{N}$ stored in above-ground biomass, litter, and roots, $\mathrm{R}^{2}<0.5$; in dry-season and wet-season, respectively) and grazing exclusion (Fig. 5).

\subsubsection{Relationship between Microbial Biomass Carbon and Nitrogen Pools and Grazing}

In our study, data showed that the soil MBC storage had decreased by $93.5 \%, 85.6 \%$, and $84.7 \%$ for plot $\mathrm{SD}, \mathrm{MD}$, and $\mathrm{LD}\left(\mathrm{R}^{2}=0.98\right.$, dry-season; $\mathrm{R}^{2}=0.50$, wet-season), respectively, and the soil MBN storage had decreased by $90.7 \%, 95.2 \%$, and $89.5 \%\left(\mathrm{R}^{2}=0.74\right.$, dry-season; $\mathrm{R}^{2}=0.50$, wet-season), respectively (Fig. 6). Therefore, a large amount of $\mathrm{MBC}$ and $\mathrm{MBN}$ has been lost in the last seven decades across grasslands subjected to long-term heavy grazing. In summary, the degradation of temperate grasslands due to longterm heavy grazing has reversed the sequestration potential and led to MBC and MBN loss by erosion and oxidation, instead of the $\mathrm{C}$ and $\mathrm{N}$ sequestration that has been desirable in the past seven decades.

\subsubsection{Relationship of Soil Fungi and Bacteria with Grazing Gradient}

The change in land-use has no significant effects on bacteria and fungi content in the grasslands of northern China. Particularly, low correlation coefficients were observed in dry-season and wet-season $\left(\mathrm{R}^{2}<0.20\right.$; $\mathrm{R}^{2}<0.65$ ) (Fig. 6). Enhanced diffusion rates of nutrients with water addition may benefit bacteria more than fungi, thereby decreasing the F/B ratio as nutrients are more efficiently transported among the four sites.

\subsection{Analysis of Driving Factors of Soil Degradation}

Our PCA analysis showed that precipitation did not contribute much more to the potentials of soil carbon and nitrogen storage (including $\mathrm{C}$ and $\mathrm{N}$ stored in above-ground biomass, litter, and roots). The soil silt and clay content may be considered to make the modest contribution to the soil degradation. The second contribution is considered to be the soil carbon and nitrogen storage. The third is the microbial biomass, and the contribution of vegetative sub-banks is greater than that of climatic conditions (Fig. 7 and Fig. 8).

Regression analysis showed that enclosure had a significant positive effect on soil particulate matter composition $(\mathrm{R}>0.90 ; P<0.01)$. Soil micro-glasses contributed more than $70 \%$ to soil nutrient pool (Fig. 6), and soil nutrient pool and microbial pool increased functionally with grazing years $(\mathrm{R}>0.50 ; \mathrm{P}<0.05)$ (Fig.6, Fig.7, and Fig.8), indicating that soil has strong dependence on and coexistence with disturbances, and soil quality degradation is a synergistic reaction of grazing disturbance intensity. Fencing is one of the most economical and effective measures for natural vegetation restoration of desertified grasslands.

\section{Discussion}

\subsection{Response of Soil Nutrient Pools to Grazing Gradient}

The far-ranging employment of free-grazing as a land-use practice is common in the temperate grasslands of northern China. A long period of overgrazing has incurred the decline of grassland productivity, deterioration of grassland, and the soil loss in vast areas (Dong and Zhang, 2005). In the semi-arid grassland, the potentials of $\mathrm{C}$ and $\mathrm{N}$ storage are approximately $17.5 \mathrm{~g} \mathrm{C} \mathrm{kg}^{-1}$ and $1.7 \mathrm{~g} \mathrm{~N} \mathrm{~kg}^{-1}$, respectively. The productivity of grasslands subjected to NG were stable or mature (Xiao et al., 1996; Bai et al., 2004). Moreover, the result from a 17-year study (2000-2017) on MD suggested that the semi-arid grasslands after more than 15 years of grazing exclusion were very weak $\mathrm{C}$ source. It had been noticed that after a long period of exclosure (i.e. $>15$ years), the $\mathrm{C}$ and $\mathrm{N}$ storage was relatively higher. Seasonal dynamic of $\mathrm{C}$ and $\mathrm{N}$ storage is not significantly different $(P>0.05)$. The same phenomenon is observed in our study. One plausible albeit theoretical account of it is that an increase in ANPP would drive greater competition for all resources, some of which are nutrients and water, and such an increased demand on nutrients would drive greater gross rates 
of soil organic matter (Fig.1). In our observation, total $\mathrm{C}$ and $\mathrm{N}$ were increased in wet-season (including above-ground biomass, ground litter, and roots). This, similarly, would likely result in more soil organic matter mineralization under natural disturbances, including large-animal grazing. Through altering soilwater content, nutrient availability and heterogeneity, productivity condition, and so forth, grazing exerts its influences on the dynamics of $\mathrm{C}$ and $\mathrm{N}$ in a grassland ecosystem (Hulbert, 1988; David et al., 1991; Collins and Smith, 2006; MacNeil et al., 2008).

Despite these caveats, the estimation of the potential storage capacity can help us systematically distinguish the effects of different management strategies on the $\mathrm{C}$ and $\mathrm{N}$ storage of grasslands in northern China. In this study, the value for site NG was about $537.2 \mathrm{~g} \mathrm{C} \mathrm{kg}^{-1}$, in alignment with the previous estimate of 10-12 $\mathrm{kg} \mathrm{C} \mathrm{m}{ }^{2}$ for the area (Wu et al., 2003), and it was higher than the global mean value of $10.6 \mathrm{~kg} \mathrm{C}$ $\mathrm{m}^{2}$ (Post et al.,1982). Burke et al.(1995) have illustrated that a 50-year period was enough for the recovery of active SOM and nutrient availability. Thus, we suggest that a MD of at least a 20-year duration would be reasonable for the restoration of the semi-arid grasslands from a state of degradation in productivity, SOC and STN storage to a similar one to natural grassland.

In this study, the soil $\mathrm{C}$ and $\mathrm{N}$ content in the surface layer is relatively high, which is due to the fact that the surface soil can adsorb newly imported organic matter quickly, thus inhibiting the primal effect and soil organic carbon mineralization. The above findings are similar to those in the early study (White et al., 1996).

\subsection{Response of Soil Microbial Pools to Grazing Gradients}

From the basic data, we observed that soil nutrient pools and soil microbial biomass pools were similar in increase or decrease based on our correlation analysis. The $\mathrm{C}$ and $\mathrm{N}$ storage varied remarkably with significant positive correlation in the microbial biomass carbon and nitrogen pools, respectively (Fig. 1, Fig. 3, and Fig. 4). And the PCA analysis indicated that silt and clay were more important contributions to the soil microbial biomass $\mathrm{C}$ and $\mathrm{N}$ storage than soil nutrient pools. Contrary to the study of predecessors, we observed that higher water availability did not play a positive role in soil nutrient pools and micro organisms.

With regard to MBC and MBN storage, the grasslands with a higher potential for MBC and MBN sequestration are those that have been depleted by poor management strategies in the past. Based on our findings, we conclude that the temperate grasslands of northern China exhibit tremendous potential for the increase of their MBC and MBN storage.

\subsection{Effects of Precipitation on Carbon and Nitrogen Pool Cycling}

This study showed minor effects of precipitation changes on the recovery of soil nutrients and their microbial biomass content (Fig. 1, Fig. 3, and Fig. 8). There is no significant effect with different precipitation patterns (Ma et al., 2020), which may be led by a high recovery, often with a low productivity at low N.

In grasslands with nutrient limits on productivity, the resistance of a natural system to a disturbance decreased, whereas its recovery/resilience increased with growing limited resource levels such as $\mathrm{N}$ and $\mathrm{P}$ (De Angelis et al., 1989), which again indicated that given limited nutrient resources, ecosystem resistance and recovery/resilience could be inversely related (Herbert et al., 1999).

Our PCA analysis revealed that precipitation did not contribute much more to soil carbon and nitrogen storage potential (including $\mathrm{C}$ and $\mathrm{N}$ stored in above-ground biomass, litter, and roots) (Fig. 8). Therefore, contrasting with resistance, the recovery of ANPP or plant growth after a dry year or a drought event was often found higher when the precipitation decreased, which was consistent with other previous studies (Fig. 2 and Fig. 6) (e.g., Xu et al., 2009). Among various ecosystems, the more severe and prolonged droughts are, the more time the ecosystems need to recover (Schwalm et al., 2017). However, in the SD, MD and LD experiment, a great increase in the recovery of nutrient with dry-season regimes may be partly attributable to the fact that the vegetation has not been permanently damaged, leaving the vegetation with the potential to survive even under pre-drought conditions (Schwalm et al., 2017). Additionally, it might be ascribed to the compensatory growth and soil nutrients' releases following rewetting (Mackie et al., 2019). Compensatory 
growth may play a critical role in the rapid recovery (Chen et al., 2020). As recently reported by Sankaran (2019), in these arid and semi-arid savannas, the ability of the plant community to recover from drought stress hinges on the length, severity and frequency of the pre-drought period. Therefore, whether and how the recovery is constrained by the pre-drought may depend on the severity and duration of the pre-drought (Xu and Zhou, 2007) as well as the growth stage of the plant (Sankaran, 2019). The results of current studies show that there is no strong effect on soil resilience following a change in rainfall regime (Fig. 1 and Fig. 2 ), which is consistent with the result in a semi-arid grassland (Xu et al., 2014). This may be due to the fact that the whole process of normal precipitation, less precipitation, and rewetting cycle is covered by the resilience metric; and an inverse correlation between resistance and recovery may indicate that a trade-off occurs with resilience.

A previous study indicated that water addition significantly increased fungal abundance in all soil aggregate classes (on average by $37.4 \%$ ). The composition of bacterial community is more affected by rainfall than that of fungal community (Manzoni et al.2012). In our study, the changes of bacteria and fungi variable by precipitation may be the effectiveness of water in wet-season. Comparatively, the content of sand and gravel contributed more to the growth of soil fungi and had a positive effect (Fig. 6), and bacteria have been found to be better adapted to the environment. Soil acidification is conducive to bacterial reproduction but not to fungal (Pennanen et al. 1998). In this study, the same conclusion can be drawn from the slow decreased change of bacteria with altered rainfall patterns. Conversely, it has also been concluded that fungi increased by as much as $80.8 \%$, which could suggest that there could be better adaption of fungi to lower soil $\mathrm{pH}$ than that of bacteria (Wang et al. 2004 ). With the increase of rainfall in the growing season, the growth rates of bacteria and fungi are different, indicating that water has different effects on different microbial groups, consistent with the results of Zhang et al. In addition, higher water availability could further improve substrate diffusion and nutrient accessibility to soil microorganisms, thereby advancing microbial growth and increasing total PLFA concentration and abundance of individual microbial communities (Dungait et al. 2012; Nielsen and Ball 2015).

We observed that given added water, there was a significant decrease in fungal abundance (Fig. 3b) and F/B ratio, indicating a change in the microbial diversity with enhanced bacterial proliferation over fungi under favorable water conditions (Griffiths et al. 1998). This may be ascribed to the different growth strategies of fungi and bacteria (hyphal growth versus individual cells) (Frey et al. 2004). Fungal hyphae can transport nutrients and resources from one microsite to other sites where nutrients are limiting their growth (Strickland and Rousk 2010). However, increased diffusion rates of nutrients with added water may be more beneficial to bacteria than to fungi, thus decreasing the $\mathrm{F} / \mathrm{B}$ ratio as nutrients are translocated more efficiently within the three soil fractions (Dungait et al. 2012).

\subsection{Response of Plant Nutrient Pools to Grazing Gradient}

Recent grassland-related field studies in Inner Mongolia showed that a plant NPP of about 1.5 tons ha ${ }^{-1}$ was limited by both $\mathrm{N}$ and water as addition above 5.25-17.5 $\mathrm{g} \mathrm{N} \mathrm{m}^{2} \mathrm{yr}^{-1}$ of background increased NPP by $13 \%-62 \%$ (Bai et al., 2010), whereas water addition increased above- and below-ground NPP by $32.9 \%$ and $38.3 \%$, respectively (Xu et al., 2010). However, soil microorganisms are not limited by the same factors that constrain plant systems (Hobbie et al.,2005; Wei et al., 2013). For instance, the study by Wei et al. (2013) showed that there were differences in $\mathrm{N}$ saturation levels (threshold levels for $\mathrm{N}$ demand) between plants and soil microorganism, emphasizing that microbes could be limited by $\mathrm{C}$ or $\mathrm{P}$ while plants were limited by $\mathrm{N}$ (Treseder, 2008). In addition, under higher $\mathrm{N}$ availability in temperate grasslands, both the size and activity of soil microbial biomass were found decreased (Gutknecht et al., 2012; Wei et al., 2013).

Plant nutrients are not limited by soil nutrients and microbial conditions, which may be due to the time and space lag of plant succession compared with soil nutrients. Vegetation replacement and nutrient status change require a long buffer period.

Soil organic carbon content decreased gradually from the NG to the SD, but the plant performance was not synchronous. Soil's response to desertification is more sensitive than vegetation, and the change of plant 
nutrients has a certain lag in time.

\section{5 Effects of Enclosure on Carbon and Nitrogen Pools}

Regression analysis showed that enclosure treatment had a significant positive effect on soil aggregates composition and nitrogen pools $(\mathrm{R}>0.90 ; \mathrm{P}<0.01)$. The soil macro-aggregates contributed more than $70 \%$ to soil nutrient storage (Fig. 6). Soil nutrient and soil microbial pools increased functionally with grazing year $(\mathrm{R}>0.50 ; \mathrm{P}<0.05)$ (Fig. 6). The recovery of the heavy-grazing area to a stable and healthy natural grassland requires more than 50 years of enclosure management (Fig.6). A large amount of evidence from previous studies suggested that a period of 10 years after enclosure of desertified grassland was a process of soil development from quantitative to qualitative change, and organic matter content reached $2.86 \%$ after 17 years of containment, 36.7 times of the initial containment. This study showed that there was a high correlation between soil nutrients and microbial nutrients pools with different grazing levels in the fenced time, and the longer control time is, the more annual nutrients return to the soil storage. And the number of soil surface bacteria in the initial stage of fenced grassland is $43.348^{*} 10^{4}$ soils/g. After 17 years of containment, $975.51 * 10^{4}$ soils/g were observed. The increase is 40.95 times of the initial containment. For SD and MD grassland, the restoration process may be promoted by reseeding of superior native plant seeds under proper organic fertilizer input and enclosure.

\section{Conclusion}

Land-use change has significant effects on $\mathrm{C}$ and $\mathrm{N}$ storage in the grasslands of northern China. The storage of $\mathrm{C}$ and $\mathrm{N}$ has decreased greatly because of grassland degradation led by long-term heavy grazing. The storage potentials of $\mathrm{C}$ and $\mathrm{N}$ in the semi-arid grasslands are approximately $537.2 \mathrm{~g} \mathrm{C} \mathrm{kg}^{-1}$ and $16.6 \mathrm{~g} \mathrm{C} \mathrm{kg}^{-1}$, respectively, so, there is huge potential for the increase of $\mathrm{C}$ storage in the temperate grasslands of northern China by improvement of grassland use or management. Micro-aggregates availability was suggested to be the main limiting factor of both NPP and microbial biomass $\mathrm{C}$ and N storage in this semi-arid grassland soil. Moreover, it is found that the site with 17 years of fencing has the highest level of soil micro-aggregates. Fencing is the most economical and effective measure for natural restoration of degraded grassland and the restoration of heavily grazed areas to stable and healthy takes at least 50 years.

\section{Acknowledgments}

We are grateful to Yongfei Bai for providing experimental platforms and also thank the staff of the field stations for their logistical support during the course of the experiment. This study was supported by The National Basic Research Program (2016YFC0500501).

\section{Author contribution}

Xiuli Gao, Junyao Liu, and Shihai Lv conceived and designed this experiment. Xiuli Gao performed the field experiment and processed the data. Daikui Li and Dewang Wang processed the data. Xiao Guan Put forward the proposal and revise the manuscript. Xiuli Gao analyzed the data and wrote the manuscript.

\section{Conflict of interest}

No conflict of interest

\section{Data accessibility statement}

All data will be uploaded in a repository once accepted.

\section{References}

Averill C, Turner BL, Finzi AC (2014)Mycorrhiza-mediated competition between plants and decomposers drives soil carbon storage. Nature 505:543-545.

White, R., Murray, S., Rohweder, M., 2000. Pilot Analysis of Global Ecosystems: Grassland Ecosystems.World Resources Institute, Washington D. C,p.81. 
Maestre, F.T., Salguero-Gomez, R., Quero, J.L., 2012. It is getting hotter in here: determining and projecting the impacts of global environmental change on drylands. Philos. Trans. R. Soc. B-Biol. Sci. 367 (1606), 3062-3075.

Kemp, D.R., Han, G., Hou, X., Michalk, D.L., Hou, F., Wu, J., et al., 2013. Innovative grassland management systems for environmental and livelihood benefits. Proc. Natl. Acad. Sci. Unit. States Am. 110 (21), 83698374 .

Davidson, E.A., Nepstad, D.C., Klink, C., Trumbore, S., 1995. Pasture soils as carbon sink. Nature 376, $472-473$.

Scurlock, J.M.O., Hall, D.O., 1998. The global carbon sink: a grassland perspective.Global Change Biology 4, 229-233.

Tan, Z., Liu, S., Johnston, C.A., Liu, J., Tieszen, L.L., 2006. Analysis of ecosystem controls on soil carbon source-sink relationships in the northwest Great Plains.Global Biogeochemical Cycles 20, GB4012, doi:10.1029/2005GB002610.

Lugo, A.E., Brown, S., 1993. Management of tropical soils as sinks or sources of atmospheric carbon. Plant and Soil 19, 27-41.

Post, W.M., Kwon, K.C., 2000. Soil carbon sequestration and land-use change: processes and potential. Global Change Biology 6, 317-327.

Jones, M.B., Donnelly, A., 2004. Carbon sequestration in temperate grassland ecosystems and the influence of management, climate and elevated CO2. New Phytologist 164, 423-439.

Billings, S.A., 2006. Soil organic matter dynamics and land use change at a grassland/forest ecotone. Soil Biology \& Biochemistry 38, 2934-2943.

Elmore, A.J., Asner, G.P., 2006. Effects of grazing intensity on soil carbon stocks following deforestation of a Hawaiian dry tropical forest. Global Change Biology

$12,1761-1772$.

Liao, J.D., Boutton, T.W., Jastrow, J.D., 2006. Storage and dynamics of carbon and nitrogen in soil physical fractions following woody plant invasion of grassland.

Soil Biology \& Biochemistry 38, 3184-3196.

Harpole, W.S., Potts, D.L., Suding, K.N., 2007. Ecosystem responses to water and nitrogen amendment in a California grassland. Global Change Biol. 13 (11), $2341-2348$.

Houghton, R.A., Hackler, J.L., Lawrence, K.T., 1999. The U.S. carbon budget: contributions from land-use change. Science $285,574-578$.

Li, Y.H., 1994. Research on the grazing degradation model of the main steppe rangelands in Inner Mongolia and some considerations for the establishment of a computerized rangeland monitoring system. Acta Phytoecologica Sinica 18, 68-79 (in Chinese with English abstract).

Dong, X.B., Zhang, X.S., 2005. The grassland in the Inner Mongolia is overloaded and change of production pattern is highlighted. Resources Science 27, 175-179 (in

Chinese, with English abstract). 
Stampfli, A., Bloor, J.M.G., Fischer, M., Zeiter, M., 2018. High land use intensity

exacerbates shifts in grassland vegetation composition after severe experimental drought. Global Change Biol. 24 (5), 2021-2034. Xu, Z., Ren, H., Cai, J., Wang, R., Li, M., Wan, S., et al., 2014. Effects of experimentallyenhanced precipitation and nitrogen on resistance, recovery and resilience of a semiarid grassland after drought. Oecologia 176 (4), 1187-1197.

Mackie, K.A., Zeiter, M., Bloor, J.M., Stampfli, A., 2019. Plant functional groups mediate drought resistance and recovery in a multisite grassland experiment. J. Ecol. 107 (2), 937-949.

Xu, Z., Wan, S., Ren, H., Han, X., Li, M.H., Cheng, W., Jiang, Y., 2012. Effects of waterand nitrogen addition on species turnover in temperate grasslands in norther china PLoS ONE 7, e3976.

Morra, M.J., Bland, R.R., Freeborn, L.L., Shafii, B., 1991. Size fractionation of soil organicmineral complexes using ultrasonic dispersion. Soil Science 152, 294-303.

Nelson, D.W., Sommers, L.E., 1982. Total carbon, organic carbon, and organic matter.

In: Page, A.L., Miller, R.H., Keeney, D.R. (Eds.), Methods of Soil Analysis.

Gallaher, R.N., Weldon, C.O., Boswell, F.C., 1976. A semi-automated procedure for

total nitrogen in plant and soil samples. Soil Science Society of America Journal 40, 887-889.

Vance, E.D., Brookes, P.C., Jenkinson, D.S., 1987. An extraction method for measuring soil microbial biomass-C. Soil Biology \& Biochemistry 19, 703-707.

Bossio DA, Scow KM (1998) Impacts of carbon and flooding on soil microbial communities: phospholipid fatty acid profiles and substrate utilization patterns. Microb Ecol 35:265-278.

Zak, D.R., Holmes, W.E., White, D.C., Peacock, A.D., Tilman, D., 2003. Plant diversity,soil microbial communities, and ecosystem function: are there any links?

Ecology 84, 2042-2050.

Pinkart HC, Ringelberg DB, Piceno YM, Macnaughton SJ, White DC (2002) Biochemical approaches to biomass measurements and community structure analysis. In: Hurst CJ (Ed) Manual of environmental microbiology. ASM Press, Washington, DC, pp 101-113.

Zhang N, Wan S, Guo J, Han G, Gutknecht J, Schmid B, Yu L, Liu W, Bi J, Wang Z, Ma K (2015) Precipitation modifies the effects of warming and nitrogen addition on soil microbial communities in northern Chinese grasslands. Soil Biol Biochem 89:12-23.

DeForest JL, Zak DR, Pregitzer KS, Burton AJ (2004) Atmospheric nitrate deposition, microbial community composition, and enzyme activity in northern hardwood forests. Soil Sci Soc Am J 68:132-138.

Dong, X.B., Zhang, X.S., 2005. The grassland in the Inner Mongolia is overloaded and change of production pattern is highlighted. Resources Science 27, 175-179 (in

Chinese, with English abstract).

Xiao, X. M., Wang, Y.F., Chen, Z.Z., 1996. Dynamics of primary productivity and soil

organic matter of typical steppe in the Xilin River basin of Inner Mongolia and their response to climate change. Acta Botanica Sinica 38, 45-52 (in Chinese,with English abstract).

Bai, Y. F., Han, X.G., Wu, J.G., Chen, Z.Z., Li, L.H., 2004. Ecosystem stability and compensatory effects in the Inner Mongolia grassland. Nature 431, 181-184.

Hulbert, L. C., 1988. Causes of fire effects in tallgrass prairie. Ecology 69, 46-58. 
David, N. T., Schimel, D.S., Owensby, C.E., Ojima, D.S., 1991. Fire and grazing in the tallgrass prairie: contingent effects on nitrogen budgets. Ecology 72, 1374-1382.

Collins, S. L., Smith, M. D., 2006. Scale-dependent interaction of fire and grazing on community heterogeneity in tallgrass prairie. Ecology 87, 2058-2067.

MacNeil, M. D., Haferkamp, M. R., Vermeire, L. T., Muscha, J. M., 2008. Prescribed fire and grazing effects on carbon dynamics in a northern mixed-grass prairie. Agriculture, Ecosystems and Environment $127,66-72$.

Wu, H. B., Guo, Z. T., Peng, C. H., 2003. Land use induced changes of organic carbon storage in soils of China. Global Change Biology 9, 305-315.

Post, W.M., Emanuel, W. R., Zinke, P. J., Stangenberger, A. G., 1982. Soil carbon pools and world life zones. Nature 298, 156-159.

Burke, I. C., Lauenroth, W. K., Coffin, D. P., 1995. Soil organic matter recovery in semiarid grasslands: implications for the conservation reserve program. Ecological Applications 5, 793-801.

Ma, Q., Liu, X., Li, Y., Li, L., Yu, H., Qi, M., et al., 2020. Nitrogen deposition magnifies the sensitivity of desert steppe plant communities to large changes in precipitation. J. Ecol. 108 (2), 598-610.

DeAngelis, D. L., Mulholland, P. J., Palumbo, A. V., Stienman, A. D., Huston, A., Elwood, J. W., 1989. Nutrient dynamics and food web stability. Annu. Rev. Ecol. Systemat. 20, 71-95.

Herbert, D. A., Fownes, J. H., Vitousek, P. M., 1999. Hurricane damage to a Hawaiian

forest: nutrient supply rate affects resistance and resilience. Ecology 80 (3), 908-920. Xu, Z., Zhou, G., Shimizu, H., 2009. Are plant growth and photosynthesis limited by predrought following rewatering in grass? J. Exp. Bot. 60 (13), 3737-3749.

Schwalm, C. R., Anderegg, W. R. L., Michalak, A. M., Fisher, J. B., Biondi, F., Koch, G., et al., 2017. Global patterns of drought recovery. Nature 548 (7666), 202-205. https://doi. org/10.1038/nature23021.

Mackie, K. A., Zeiter, M., Bloor, J. M., Stampfli, A., 2019. Plant functional groups mediate drought resistance and recovery in a multisite grassland experiment. J. Ecol. 107 (2), 937-949.

Chen, N., Zhang, Y., Zu, J., Zhu, J., Zhang, T., Huang, K., et al., 2020. The compensation effects of post-drought regrowth on earlier drought loss across the Tibetan plateau grasslands. Agric. For. Meteorol. $281,107822.2019 .107822$.

Sankaran, M., 2019. Droughts and the ecological future of tropical savanna vegetation. J. Ecol. 107 (4), 1531-1549.

Xu, Z., Zhou, G., 2007. Photosynthetic recovery of a perennial grass Leymus chinensis after different periods of soil drought. Plant Prod. Sci. 10 (3), 277-285. Sankaran, M., 2019. Droughts and the ecological future of tropical savanna vegetation. J. Ecol. 107 (4), 1531-1549.

Xu, Z., Ren, H., Cai, J., Wang, R., Li, M., Wan, S., et al., 2014. Effects of experimentallyenhanced precipitation and nitrogen on resistance, recovery and resilience of a semiarid grassland after drought. Oecologia 176 (4), 1187-1197.

Manzoni S, Schimel J P, Porporato A (2012) Responses of soil microbial communities to water stress: results from a meta-analysis. Ecology 93:930-938.

Pennanen T, Fritze H, Vanhala P, Kiikkila O, Neuvonen S, Baath E (1998) Structure of a microbial community in soil after prolonged addition of low levels of simulated acid rain. Appl Environ Microb 64:2173-2180.

Ruzhen, Wang, Maxim, et al. Sensitivities to nitrogen and water addition vary among microbial groups within soil aggregates in a semiarid grassland[J]. Biology and Fertility of Soils, 2016. 
Zhang, N., Liu, W., Yang, H., Yu, X., Gutknecht, J.L.M., Zhang, Z., Wan, S., Ma, K.,

2013a. Soil microbial responses to warming and increased precipitation and their implications for ecosystem C cycling. Oecologia 173, 1125e1142.

Dungait J A, Hopkins D W, Gregory A S, Whitmore A P (2012) Soil organic matter turnover is governed by accessibility not recalcitrance. Glob Chang Biol 18:1781-1796.

Nielsen U N, Ball B A (2015) Impacts of altered precipitation regimes on soil communities and biogeochemistry in arid and semi-arid ecosystems. Glob Chang Biol 21:1407-1421.

Griffiths B S, Ritz K, Ebblewhite N, Dobson G (1998) Soil microbial community structure: effects of substrate loading rates. Soil Biol Biochem 31:145-153.

Frey S D, Knorr M, Parrent J L, Simpson R T (2004) Chronic nitrogen enrichment affects the structure and function of the soil microbial community in temperate hardwood and pine forests. Forest Ecol Manag 196:159-171.

Strickland M S, Rousk J (2010) Considering fungal: bacterial dominance in soils-methods, controls, and ecosystem implications. Soil Biol Biochem 42:1385-1395.

Bai Y, Wu J, Clark C M, Naeem S, Pan Q, Huang J, Zhang L, Han X (2010) Tradeoffs and thresholds in the effects of nitrogen addition on biodiversity and ecosystem functioning: evidence from Inner Mongolia grasslands. Glob Chang Biol 16:358-372.

Xu, Z., Wan, S., Zhu, G., Ren, H., Han, X., 2010. The inflfluence of historical land use and water availability on grassland restoration. Restoration Ecology 18, 217e225.

Hobbie, E. A., Jumpponen, A., Trappe, J., 2005. Foliar and fungal 15N: $14 \mathrm{~N}$ ratios reflect development of mycorrhizae and nitrogen supply during primary succession:

testing analytical models. Oecologia 146, $258 \mathrm{e} 268$.

Wei, C., Yu, Q., Bai, E., Lu, X., Li, Q., Xia, J., Kardol, P., Liang, W., Wang, Z., Han, X., 2013.Nitrogen deposition weakens plantemicrobe interactions in grassland ecosystems. Global Change Biology 19, 36883697 .

Treseder, K. K., 2008. Nitrogen additions and microbial biomass: a meta-analysis of ecosystem studies. Ecology Letters 11, 1111-1120.

Gutknecht, J. L. M., Field, C. B., Balser, T. C., 2012. Microbial communities and their responses to simulated global change fluctuate greatly over multiple years.Global Change Biology 18, 22562269.

Wei, C., Yu, Q., Bai, E., Lu, X., Li, Q., Xia, J., Kardol, P., Liang, W., Wang, Z., Han, X., 2013.Nitrogen deposition weakens plantemicrobe interactions in grassland ecosystems. Global Change Biology 19, 36883697 .

Table 1 Characteristics of experimental plots (DS, dry-season; WS, wet-season)

\begin{tabular}{|c|c|c|c|c|c|c|c|c|}
\hline $\begin{array}{l}\text { Land- } \\
\text { use } \\
\text { types }\end{array}$ & $\begin{array}{l}\text { Location DominanpH } \\
\text { and } \\
\text { sub- } \\
\text { dominant } \\
\text { species }\end{array}$ & $\begin{array}{l}\text { Sand } \\
(\%)\end{array}$ & $\begin{array}{l}\text { Silt } \\
(\%)\end{array}$ & $\begin{array}{l}\text { Clay } \\
(\%)\end{array}$ & $\begin{array}{l}\text { Clay } \\
(\%)\end{array}$ & $\begin{array}{l}\text { Clay } \\
(\%)\end{array}$ & $\begin{array}{l}\text { Clay } \\
(\%)\end{array}$ & $\begin{array}{l}\text { GrasslandGrasslandand- } \\
\text { ConditiorConditionse } \\
\text { history }\end{array}$ \\
\hline
\end{tabular}


SD $116^{\circ} 38^{\prime}$ L.chinensis,Stgiandis, $43^{\circ} 24^{\prime}$ frigida Willd.,Salsola

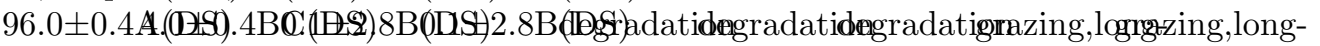

colterm term

lina heavy heavy

Pall., grazing grazing

Achnatherum

sibiricum

Keng

$\mathrm{MD} \quad 116^{\circ} 39^{\prime} \mathrm{L}$, chi$43^{\circ} 33^{\prime}$ nensis, S.

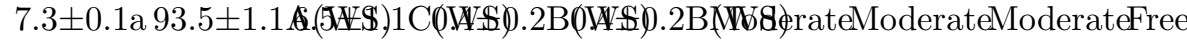

grandis, C. squarrosa,

A.

frigida, Kochia prostrate Schrad,

A. sibiricum

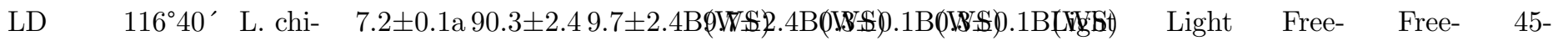
$43^{\circ} 33^{\prime}$ nensis, S.

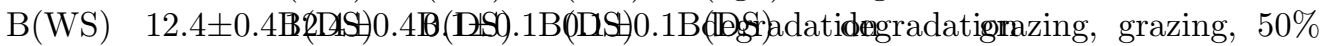
gran$87.6 \pm 0.4 \mathrm{~B}(\mathrm{DS})$ dis, C. squarrosa, A. sibiricum, A. frigida, S. collina 
NG $116^{\circ} 16^{\prime}$

L. chi- 7.1

7.1

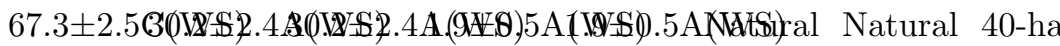

40-ha

plot

sis, S.

gran-

dis,

A.

mich-

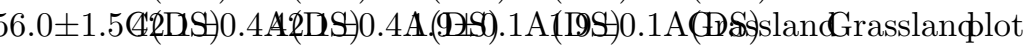

that

has

that

has

been

been

noi,

fenced

fenced

A.

since

since

sibir-

icum,

C.

squar-

rosa,

Carex

korshinskyi

$\mathrm{SD}$, severe degradation; MD, moderate degradation; LD, light degradation; NG, natural grassland. Values $(0-10 \mathrm{~cm}$ soil layer) represented as mean $\pm \operatorname{SEM}(\mathrm{n}=5)$ and designated by the same letters in the same column are not significantly different at $P<0.05$. 


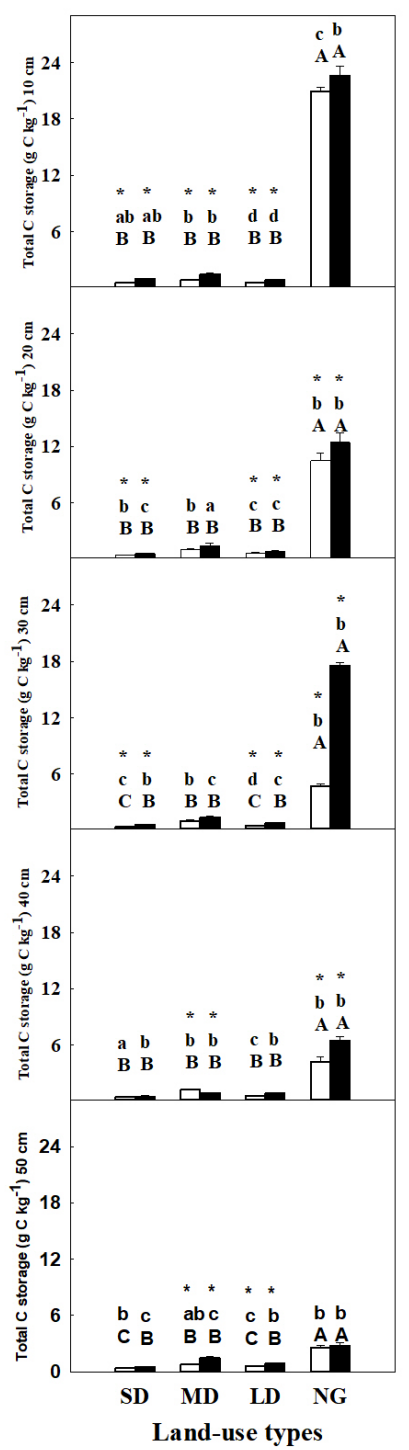




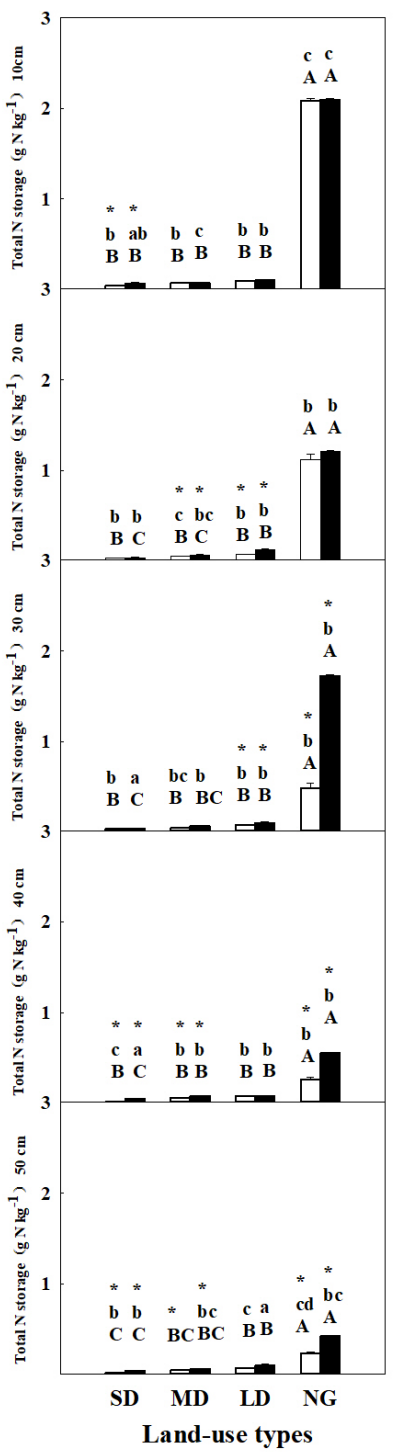

Fig. 1. Changes in total $\mathrm{C}$ (1a) storage, and total $\mathrm{N}$ storage (1b) based on different land-use types in a semi-arid grassland of northern China (i.e. top 50-cm soil layer). Data are represented as mean \pm SEM (n $=5)$. See Table 1 for site abbreviations. 


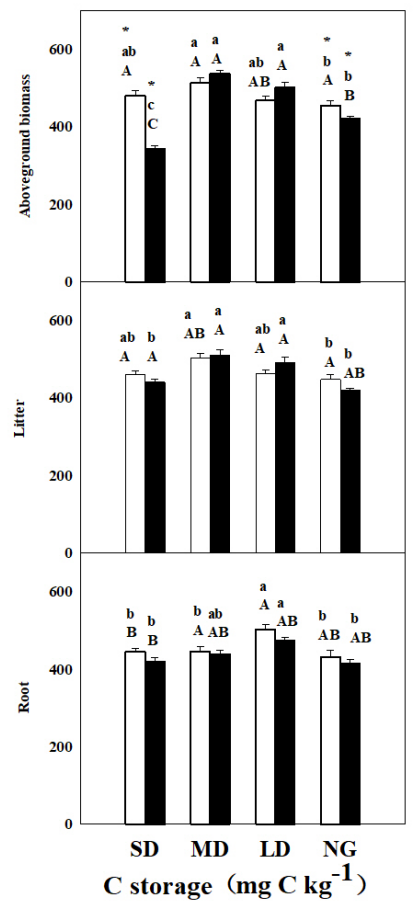




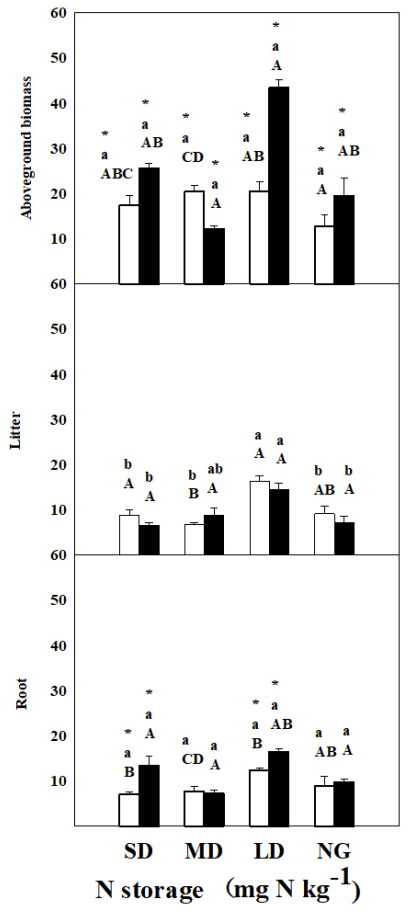

Fig. 2. $\mathrm{C}$ and $\mathrm{N}$ storage in above-ground biomass (2a), litter (2b), and roots (2c) based on different land-use types in a semi-arid grassland of northern China. Data are represented as mean \pm SEM $(n=5)$. See Table 1 for site abbreviations. 


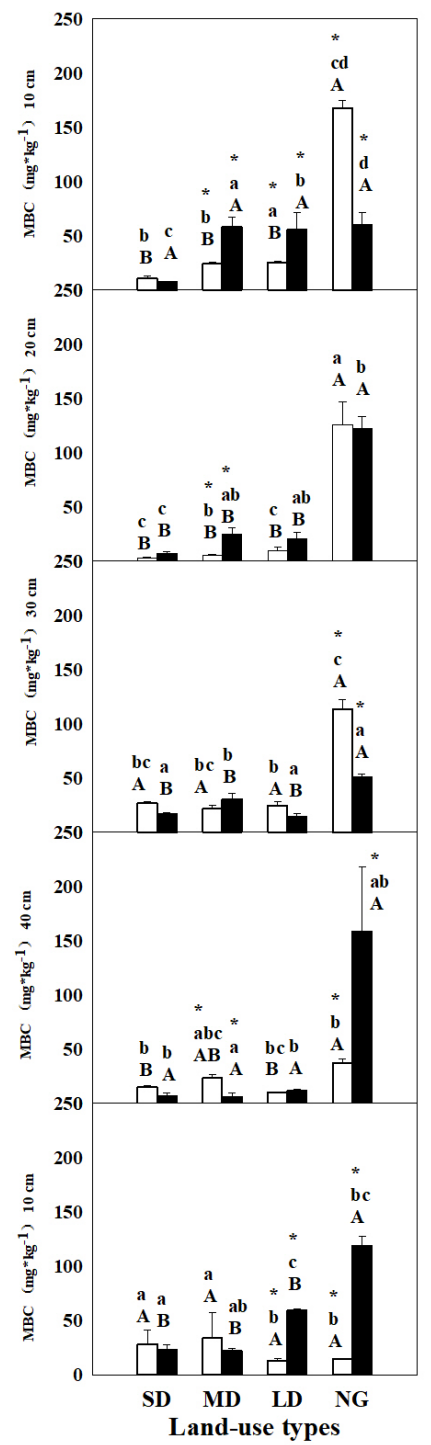




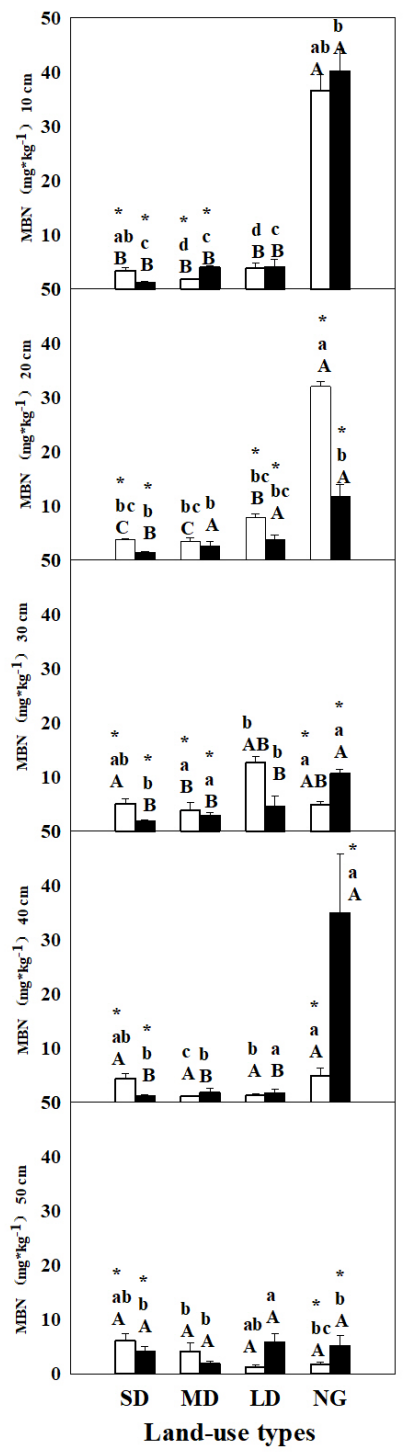

Fig. 3. Microbial biomass $\mathrm{C}(3 \mathrm{a})$ and $\mathrm{N}(3 \mathrm{~b})$ concentration and distribution based on soil depth in the different land-use types in a semi-arid grassland of northern China. Horizontal bars indicate SEM ( $=5)$. See Table 1 for site abbreviations. 


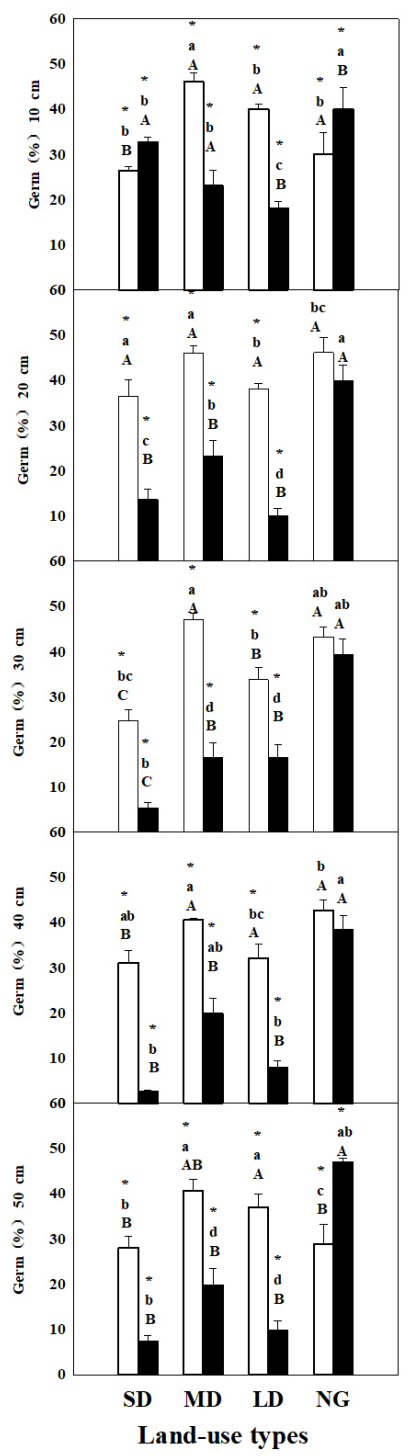




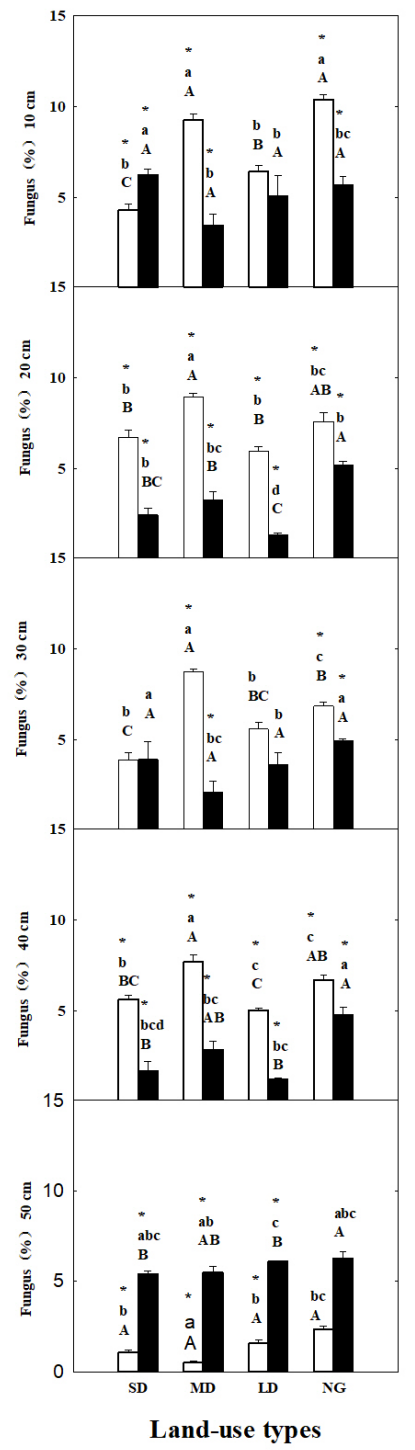

Fig. 4. Percentage of bacteria (4a) and fungi (4b) distribution based on soil depth in the different land-use types in a semi-arid grassland of northern China. Horizontal bars indicate SEM $(n=5)$. See Table 1 for site abbreviations. 


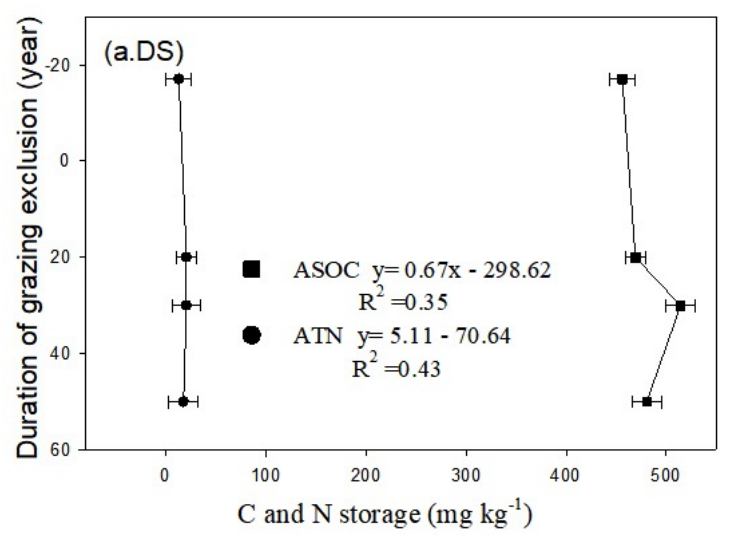

$\mathrm{C}$ and $\mathrm{N}$ storage $\left(\mathrm{g} \mathrm{kg}^{-1}\right)$

A. sph

$\longrightarrow$ A. int 

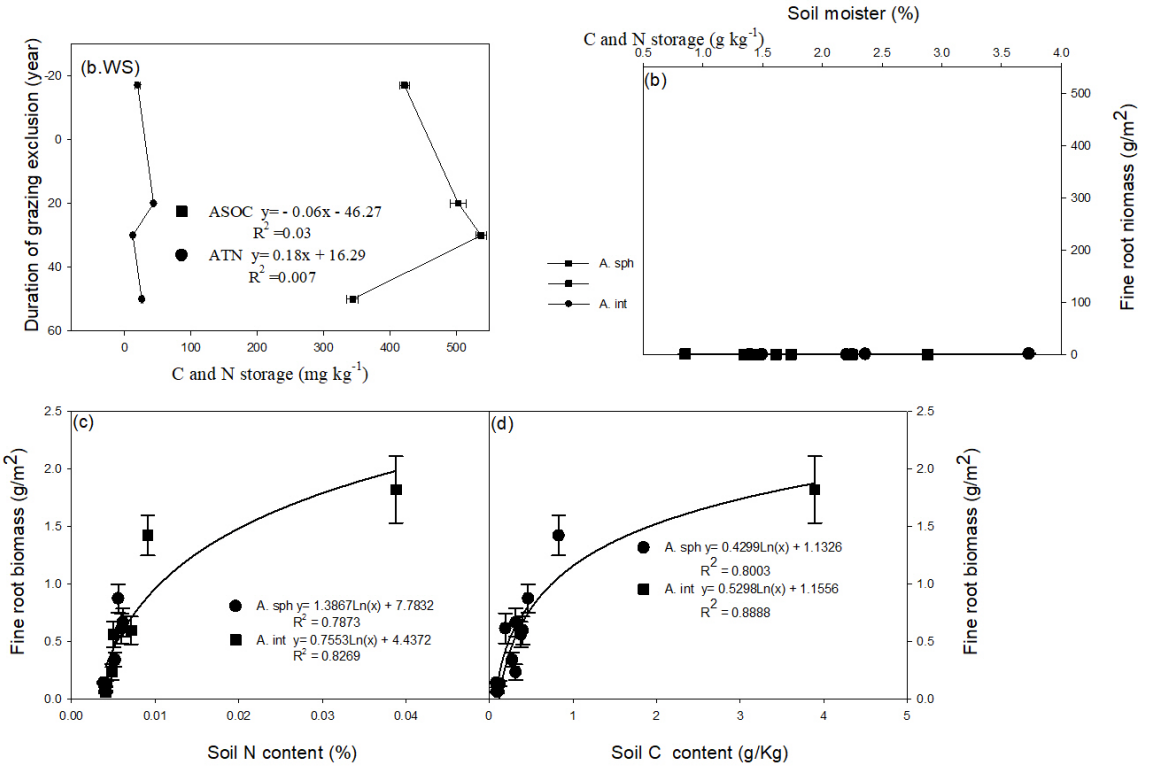


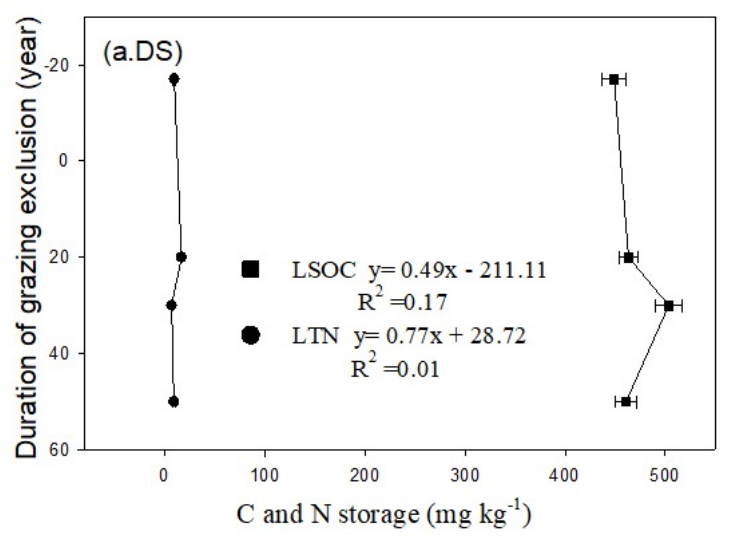

$\mathrm{C}$ and $\mathrm{N}$ storage $\left(\mathrm{g} \mathrm{kg}^{-1}\right)$

$\longrightarrow$ A. sph 

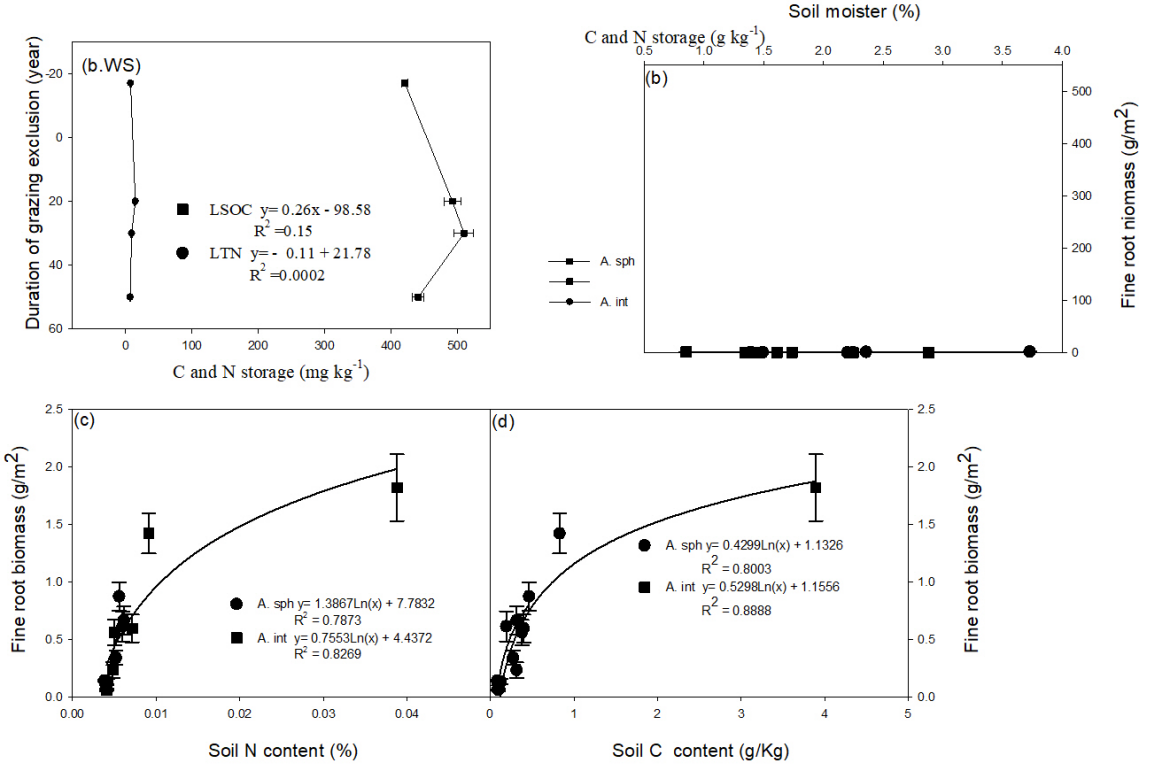

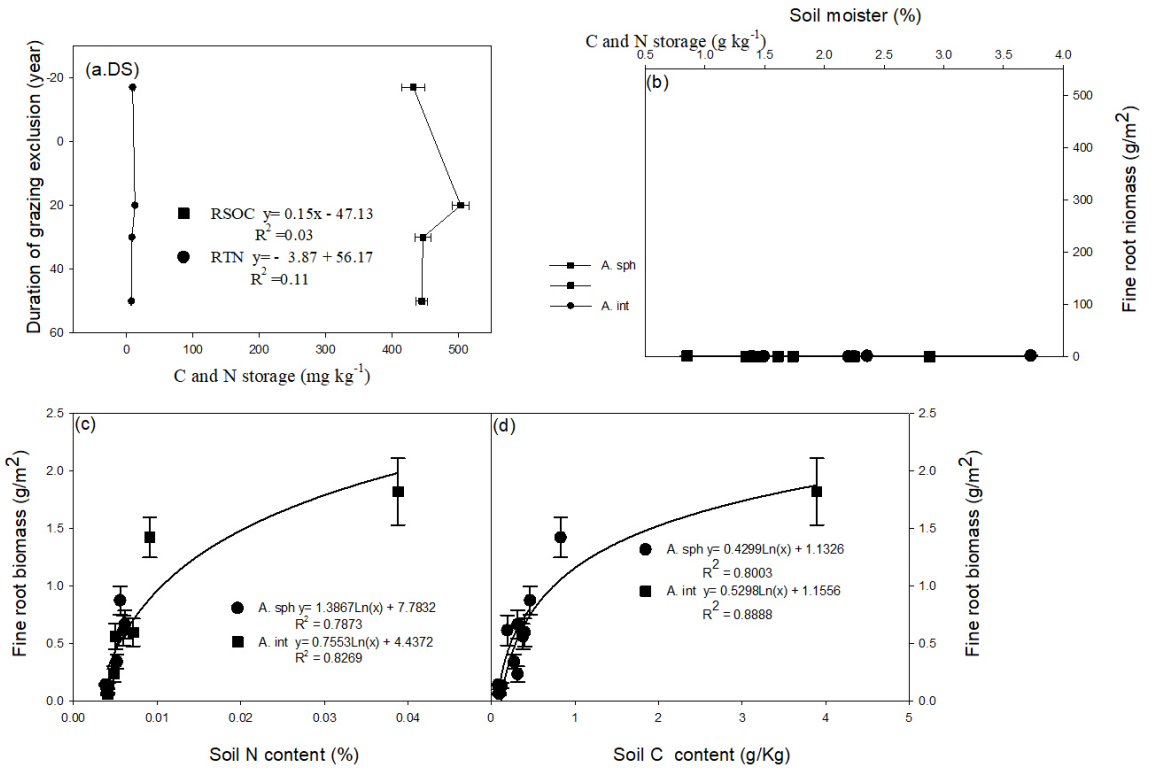

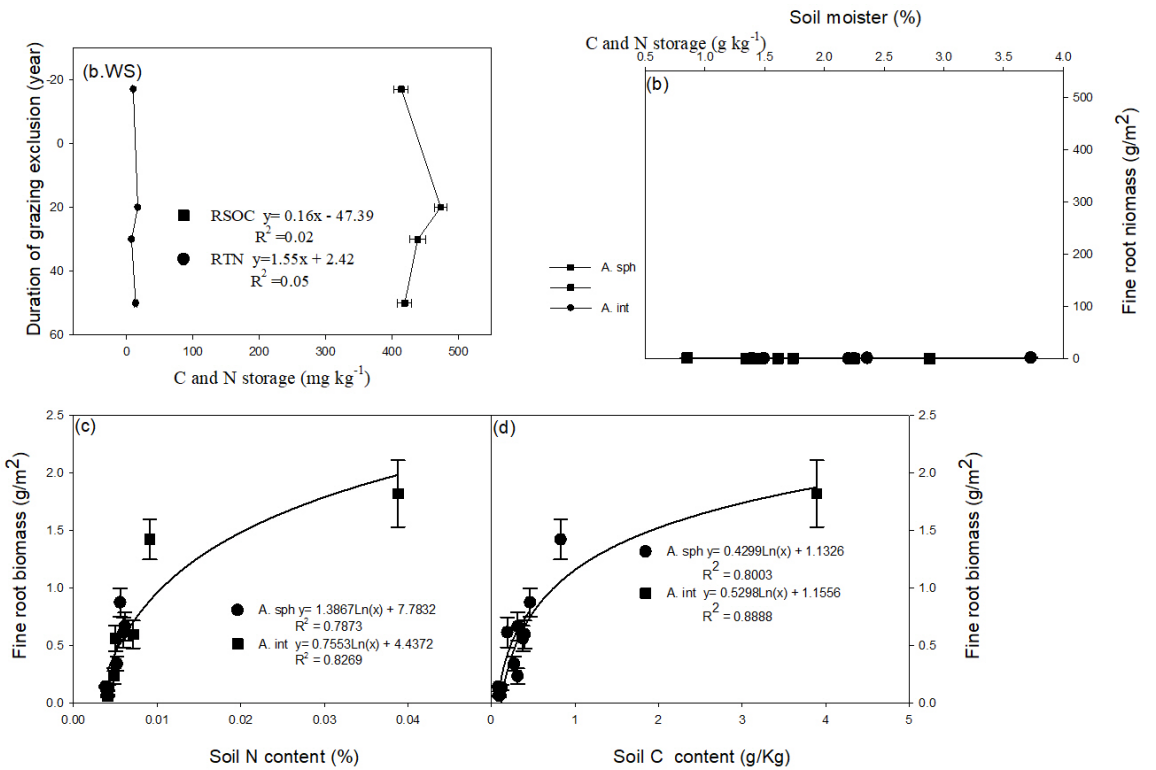

Fig. 5. Relationship between plants nutrient pools and grazing in dry-season (5a) and wet-season (5b). Horizontal bars indicate SEM $(\mathrm{n}=5)$. 


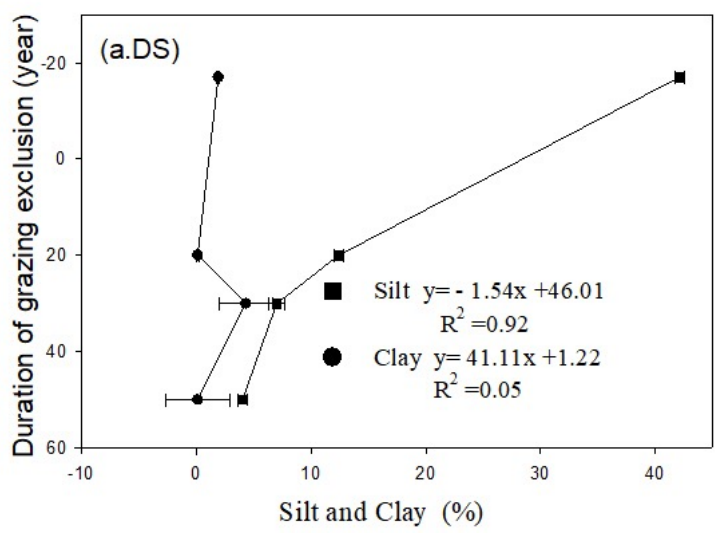

$\mathrm{C}$ and $\mathrm{N}$ storage $\left(\mathrm{g} \mathrm{kg}^{-1}\right)$

A- Aph 

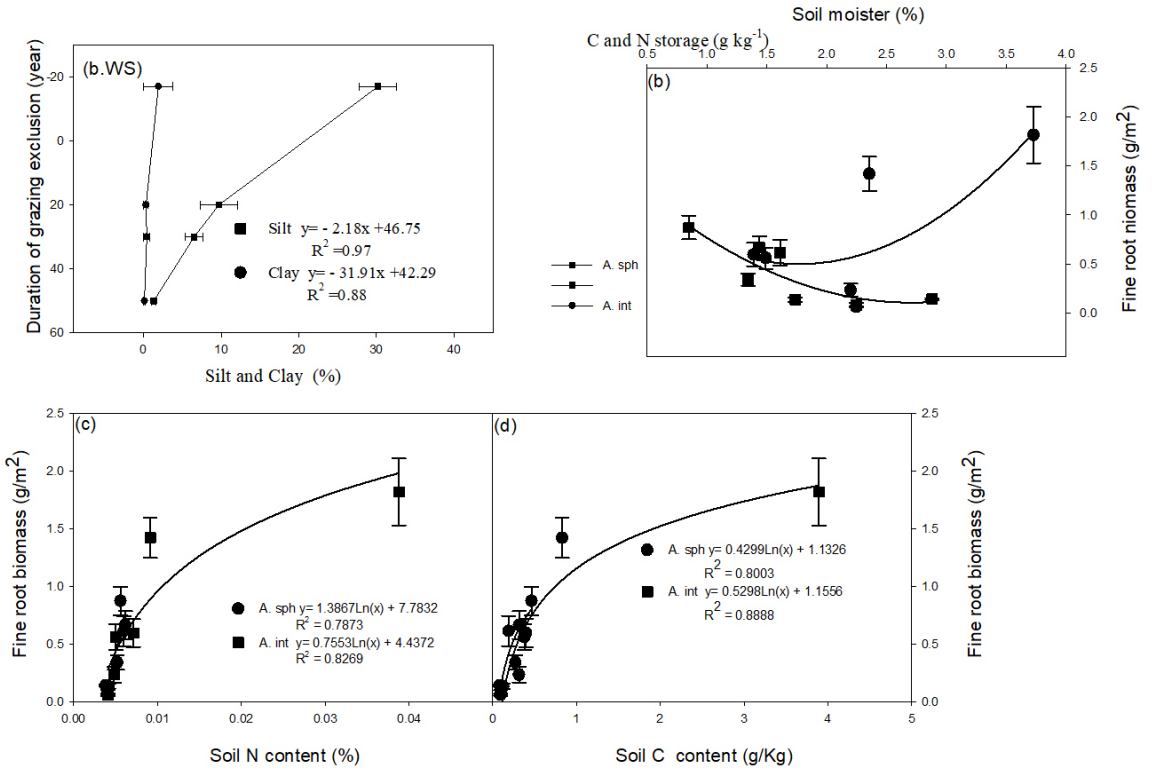


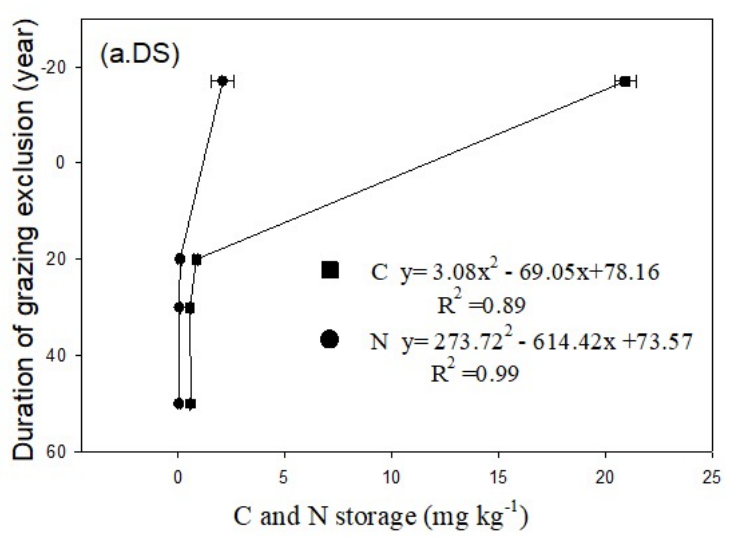

$\mathrm{C}$ and $\mathrm{N}$ storage $\left(\mathrm{g} \mathrm{kg}^{-1}\right)$
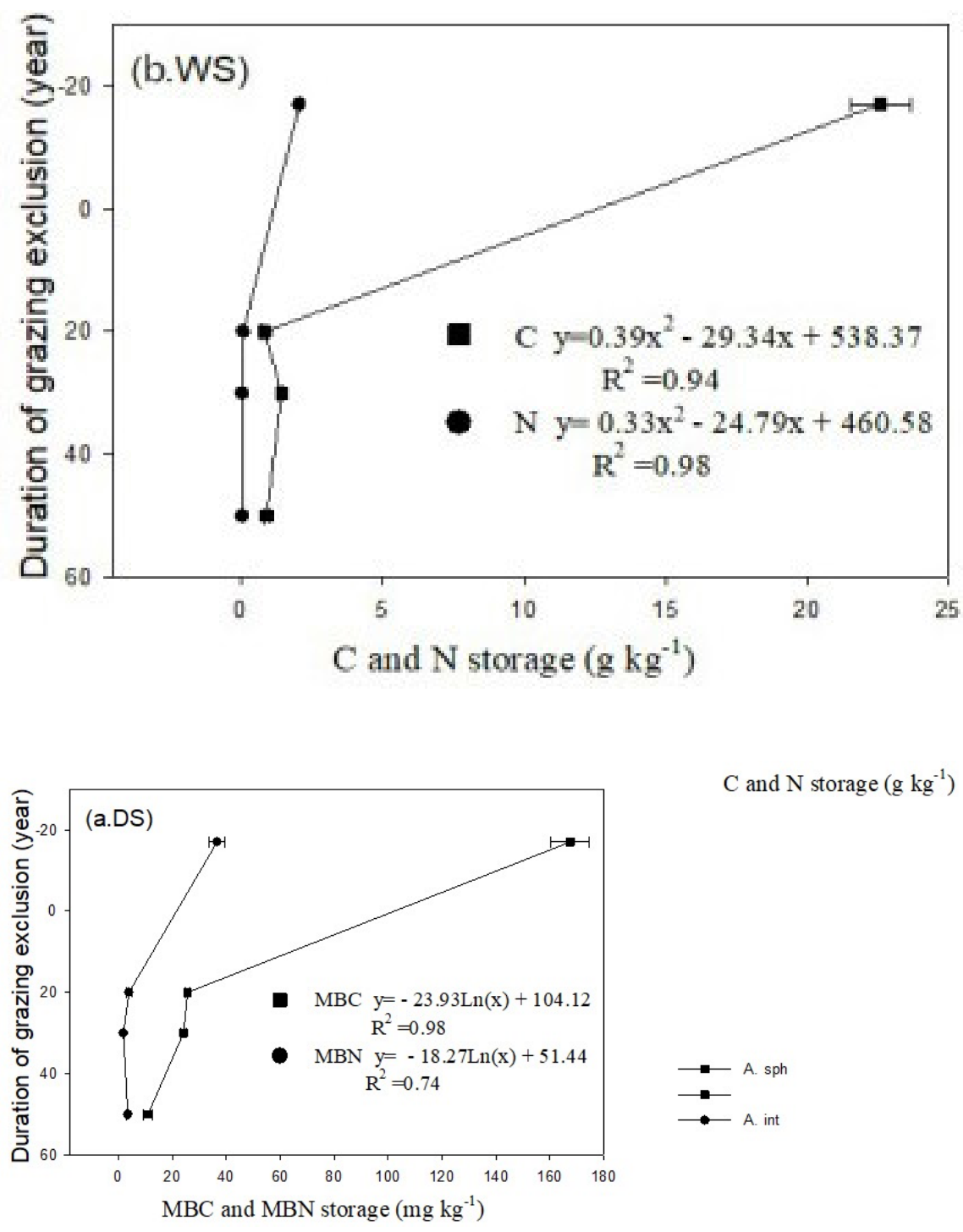

$\mathrm{C}$ and $\mathrm{N}$ storage $\left(\mathrm{g} \mathrm{kg}^{-1}\right)$ 


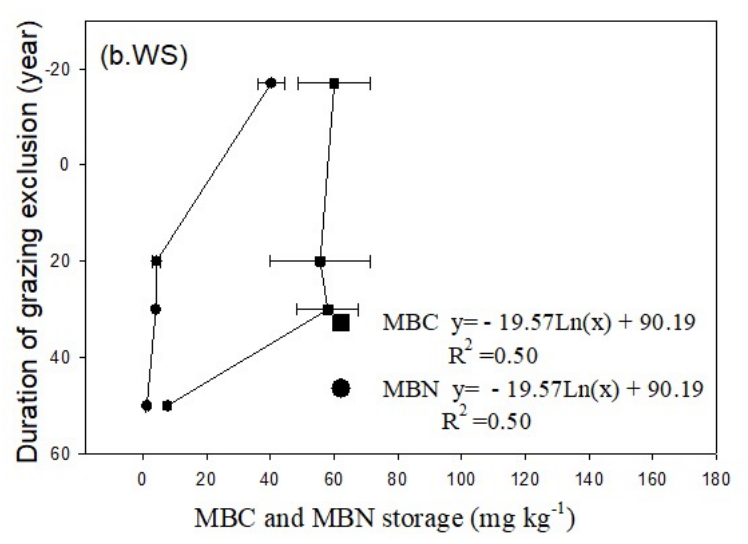

C and $\mathrm{N}$ storage $\left(\mathrm{g} \mathrm{kg}^{-1}\right)$

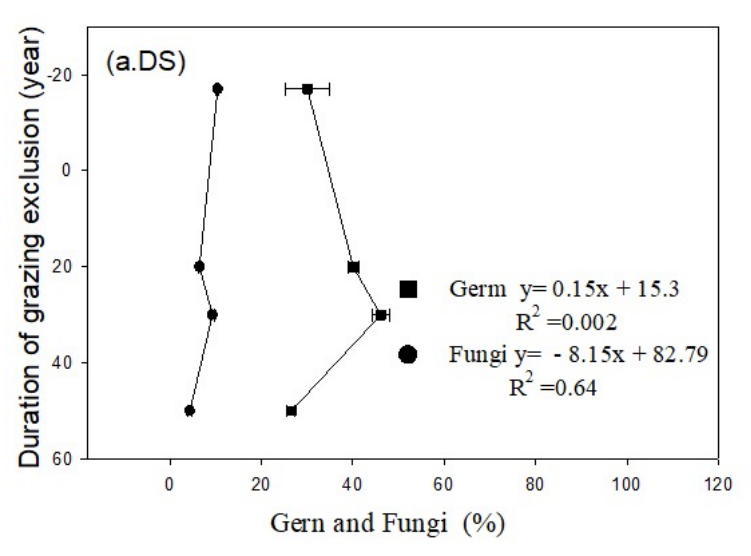

A. sph

$\mathrm{C}$ and $\mathrm{N}$ storage $\left(\mathrm{g} \mathrm{kg}^{-1}\right)$

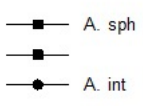



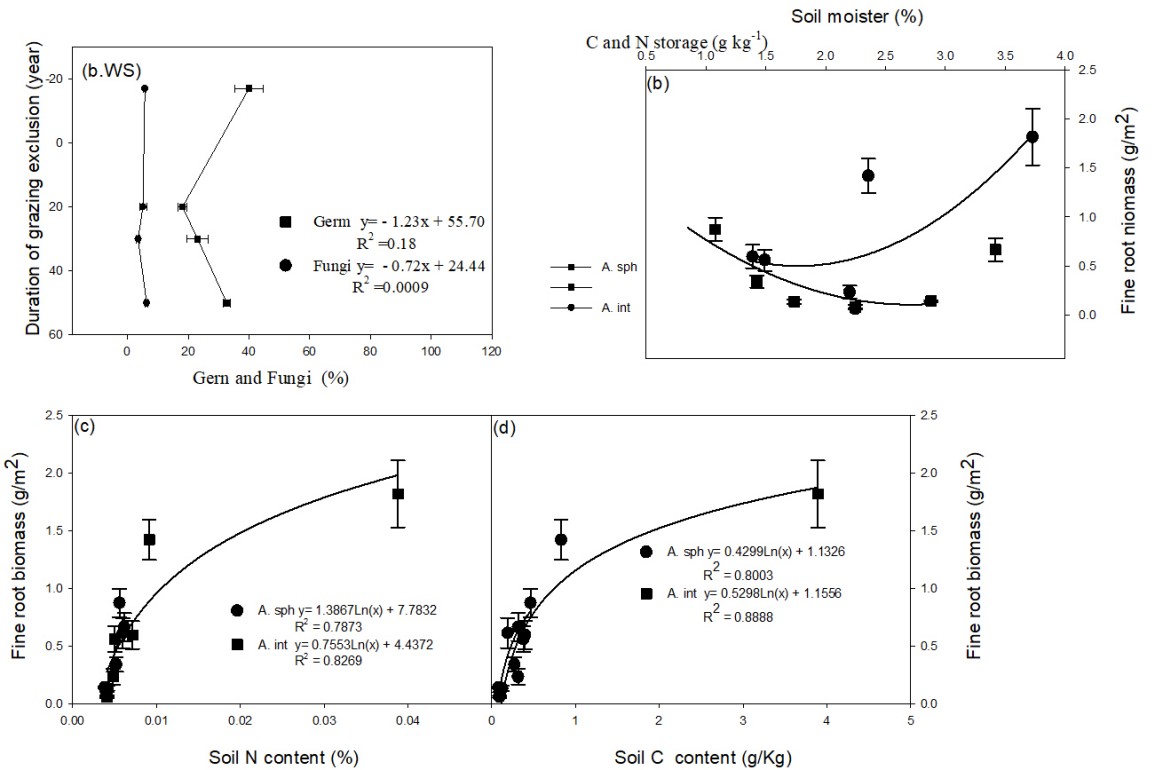

Fig. 6 Changes in soil nutrients pools and microbial pools storage with the duration of grazing exclusion (year) (Dry-season, 6a; Wet-season, 6b). Horizontal bars indicate SEM $(\mathrm{n}=5)$. 


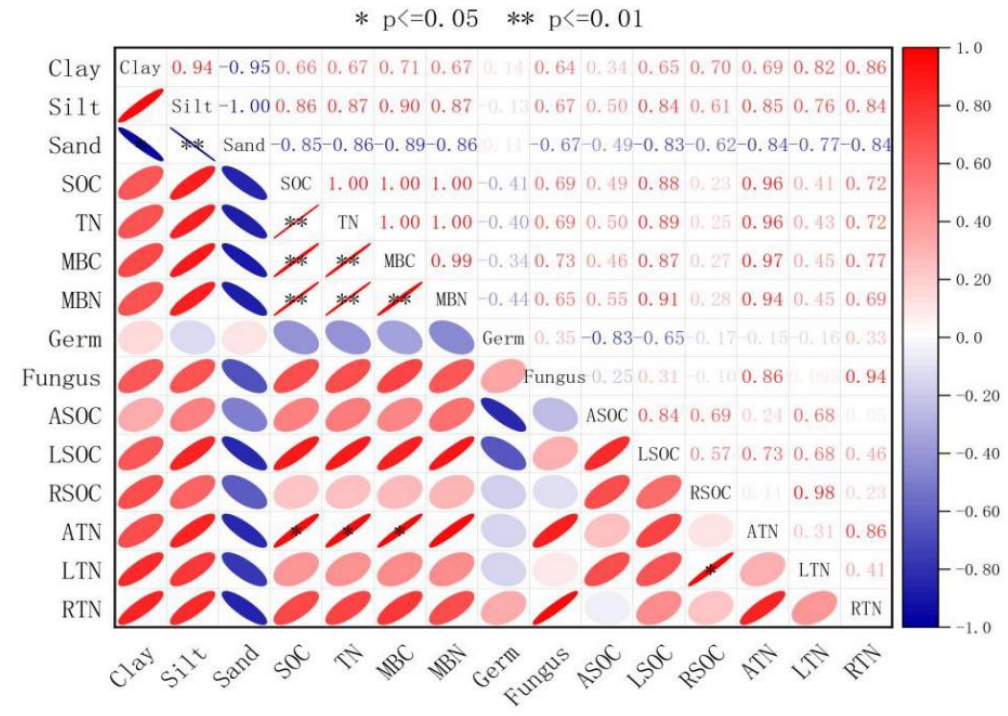

Fig. 7. Correlation Diagram

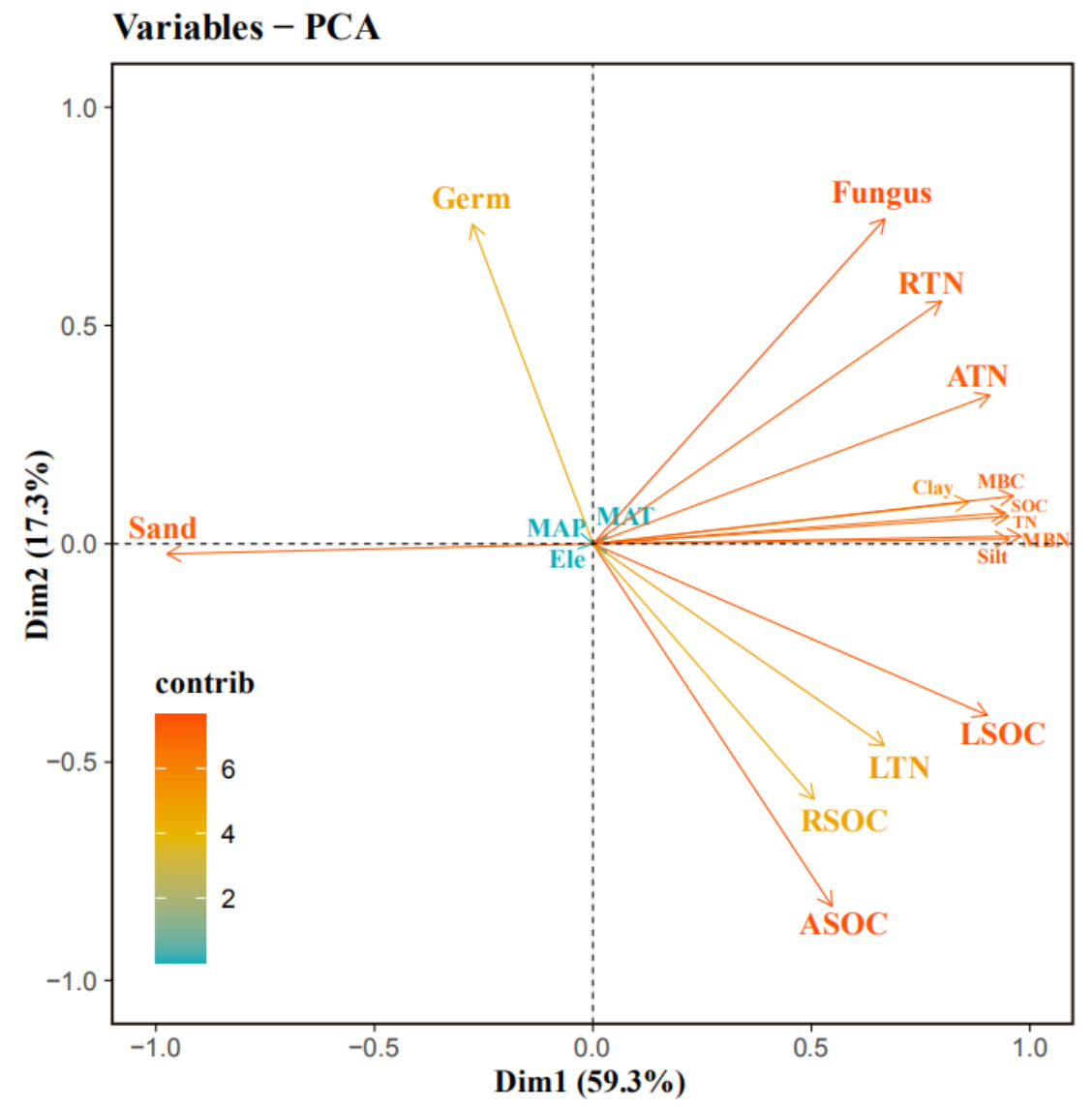


Fig. 8 PCA Analysis 